\title{
Antik Kastabala Kenti Kuzey Kilise Üzerine Gözlemler: Uzam, Mekan ve Anlamsal Üretim Döngüisü
}

\section{Observations on Ancient Castabala City North Church: Space, Mass and Semantic Production Cycle}

\author{
R. Eser Kortanoğlu ${ }^{1}$ (1), Ferda Barut Kemirtlek ${ }^{2}$ (1)
}

'Sorumlu yazar/Corresponding author: R. Eser Kortanoğlu (Doç. Dr.),

Anadolu Üniversitesi, Yunus Emre Kampüsü, Edebiyat Fakültesi, Arkeoloji Bölümü, Klasik

Arkeoloji Anabilim Dalı, Eskişehir, Türkiye

E-posta: eserkortanoglu@gmail.com

ORCID ID: 0000-0002-7903-9498

2Ferda Barut Kemirtlek (Dr. Öğr. Üyesi)، Anadolu Üniversitesi, Yunus Emre Kampüsü, Edebiyat Fakültesi, Arkeoloji Bölümü, Klasik Arkeoloji Anabilim Dalı, Eskişehir, Türkiye

E-posta: ferdabarut@gmail.com ORCID ID: 0000-0002-7568-8431

Başvuru/Submitted: 13.06 .2020

Kabul/Accepted: 04.09.2020

Atıf/Citation: Kortanoglu, R. E., \& Barut Kemirtlek, F. (2020). Antik Kastabala kenti Kuzey Kilise üzerine gözlemler: Uzam, mekan ve anlamsal üretim döngüsü. Anadolu AraștrrmalarıAnatolian Research, 23, 261-288. https://doi.org/10.26650/anar.2020.23.752518

\section{öz}

Antik Kilikia Bölgesi'nin Kastabala kenti, Geç Hellenistik Dönem'de Roma'nın vasal kralı Tarkondimotos ile bölgenin tarihselliğinde öne çıkmaya başlamış ama özellikle de Roma İmparatorluk Dönemi'nde en görkemli halini yaşamıştır. Roma İmparatorluk Dönemi'nde, MS 2-3. yüzyıllarda kentte sütunlu cadde ve anıtsal birçok yapı inşa edilmiştir. Geç Antik Çağ’ın başlamasıyla, Hıristiyanlık ile birlikte tapımdaki tekilliğin kendine özgü kutsal yapıları da kentte inşa edilmiştir. Bu bağlamda kentte "Kuzey Kilise" ve "Güney Kilise" olarak adlandırılmış yapılar kentin İmparatorluk Dönemi anıtsal yapılarına ait mimari öğelerin yeniden kullanılmaları ile inşa edilmiştir. Makale öznesi olarak Kuzey Kilise'ye odaklanmıştır. Kuzey Kilise bağlamında söz konusu inşa paradoksal bir anlam kazanmıştır. Bunun temel nedeni blokların ve mimari malzemelerin normalde kullanılması gereken yerlerde konumlandırılmamış olmalarıdır. Makalede Kuzey Kilise olarak anılan anıtsal kütle; spolia malzemenin kullanımı, dekonstrüksiyon, Genius Loci kavramı ve Artemis Perasia tapınımı, Roma'nın tanı imparatorları, özellikle Pavlus üzerinden Hıristiyanlığın kurulumu ve bu kurulumun post-yapısalcı eleştiri üzerinden yorumlanması çerçevesinde incelenmiştir. Bunun dışında Kilikia Bölgesi ve Anadolu bağlamında kilise mimarisi ve plan tipolojisi açısından da anıtsal Kuzey Kilise, belirli bağlam ve kümesel ilişkiler çerçevesinde değerlendirilmiştir.

Anahtar Kelimeler: Kilikia, Kastabala, Kilise, Ana Tanrıça, Artemis, Hıristiyanlık

\section{ABSTRACT}

Castabala in Ancient Cilicia is a city became prominent during Late Hellenstic period during the reign of Tarkondimotos, vassal king of Rome. The golden age of the city was its time under the Roman Imperial Period. During this period, in 2nd and $3 r d$ centuries $A D$, a colonnaded street and other monumental buildings were built. In Late Antiquity, idiosyncratic sacred structures/buildings of the singularity of worship were also built in the city. In this context, the buildings named "North Church" and "South Church" were built by re-using of the architectural elements of the monumental buildings of Roman Empire period of the city. North Church is the main subject to be focused in this paper. In the context of Kuzey Kilise, the construction in question takes on a paradoxical meaning. The main reason of it is that the blocks and architectural elements not to be situated in the places which normally they had to be. The monumental mass as called North Church within the 
scope of the article is analyzed within the frame of the spolia, deconstruction, Genius Loci concept and Artemis Perasia cult, the God-Emperors of Rome, the construction of Christianity via Paul and the interpretation of this construction in the context of poststructuralist critique. Besides, North Church edifice is commentated within the frame of certain contexts and clusteral relationships in terms of church architecture and typology in the context of Cilicia and Anatolia.

Keywords: Kilikia, Kastabala, Church, Mother Goddess, Artemis, Christianity

\section{EXTENDED ABSTRACT}

Castabala is an ancient city in Cilicia and as Hierapolis it owes its title to Artemis Perasia. Castabala Hierapolis which became prominent during Late Hellenstic period during the reign of Tarkondimotos, got involved in three different transcendental-personality during its historicity: Magna Mater through Artemis Perasia cult, Apotheosis of Roman Empire through Tarkondimotos, and the almighty God of Christianity. In this paper, the North Church of Castabala as an important indicator of these three constituents is aimed at to be analyzed within the context of its different structural and semantical construction/ deconstruction phases. In this analysis, we aim to evaluate the meaning and the function of the building on the basis of the reconstruction of the material in a deconstructive way and to analyze the correlation between the monument, the space, and the material by the way of the contemporary concepts like Genius Loci (Norberg-Schulz), Field (Bourdieu), Pastoral Power (Foucault), and Deconstruction (Derrida).

Christianity in Cilicia is dated back to the apostolic period in the first century. Saint Paul, one of the most important figures of Christianity, is from Cilicia and some biblical records of his visits in the area indicate that there were Christian communities there starting from the first century. During the fourth century, Cilician bishops had important roles on the local and the central church policies. Hierapolis Castabala which was listed as a bishopric center in early period is on the way of Roman itinerary and is nearer to the pilgrimage route. Archaeological and literary sources indicate that there were many churces in Cilicia and Isauria during the Late Antiquity. In Hierapolis Castabala there are two similar churches dating the fifth-sixth centuries: The North Church and the South Church.

The conversion of the Sacred both in the context of the belief and its instruments can be observed in the case of Castabala. The new religious system brings its own liturgical and architectural luggage but sees no harm to use the present material in a new context at the same time. The North Church is a reconstruction operation in the context of the usage of its material chronology. In ancient architecture, materials and construction elements function in certain contexts and are named in accordance with their defined forms and functions. Nevertheless, in the case of the North Church, the reconstruction process gained a paradoxical identity due to the unusual/reversal arrangement of its architectural elements. Some of its

architectural elements dated on the second century are spolia and they function differently, in fact reversally from their original functions. 
The meaning of the architectural form as a cultural element leave traces which makes it possible for us to define it. These traces as substantive indicators of meaning which are constructed in this cultural topography once but are not there anymore make it possible to read the specific nature of the monumental blocks. But in the case of the North Church, the situations seems paradoxical. The orthostates which are normally situated on the level of stylobates were placed on the highest level of the entablature; the capitals were used as imposts and the architraves were placed at the lowest level. Consciously or not, this is a remarkable praxis and constitutes a peculiar arrangement. This kind of usage of spolia caused the losing of the semantic and decorative character of the material and placed them only as a part of statical order. Consequently, the North Church was completely constructed by the misapplication of the original function and the semantical structure of the materials which lost their original aims in the meaning of function, situation, and decoration. In other words, they lost their names, functions, and meanings. The original structure and/or the meanings of the structures were deconstructed in order to construct/reconstruct a monument. 


\section{Giriş}

Tarihselliği içerisinde Kastabala Kenti üç farklı aşkın-karaktere aidiyet göstermiştir; Artemis Perasia kültü üzerinden Anadolu Ana Tanrıçasına (bu tapınım onu Hierapolis Kastabala haline getirmiştir), vasal kral Tarkondimotos üzerinden Cumhuriyet (Pompeius/ Antonius - fiili iktidar) ve sonrasında İmparatorluk Roma'sına (artık bir Tanrı olmuş imparatora), sonuncu olarak da Hıristiyanlık Dönemi tekilliğine (Tek Tanrı'ya). Farklı yapısal ve anlamsal inşa/söküm evrelerini sunmak istediğimiz Kuzey Kilise kütlesi bu üç dominant tarihsel üst-öğenin önemli bir birleşik göstergesidir. Bu birleşimin farklı dönemlerde ve farklı şekillerde inşa, söküm, yeniden inşa edimleri ve aşağıda görüleceği üzere kuşkusuz bunların derin anlamsal yansımaları söz konusu olmuştur.

Anadolu'da, Antik Kilikia Bölgesi'nin Ovalık kısmında (Pedias), Osmaniye il merkezi ile Karatepe-Aslantaş arkeolojik alanları arasında Kastabala (veya Hierapolis Kastabala) kenti bulunmaktadır (fig. 1). Kent tarihsel gelişmeler sonucunda kısmen Geç Hellenistik Dönem'de (veya Roma Geç Cumhuriyet Dönemi) Tarkondimotos ile kavuştuğu hiyerarşi ile öne çıkmaya başlamış (Sayar, 1999b, 207; Sayar, 2001, 373-380; Tobin, 2001, 381-387; Sayar, 2016, 105; Sayar, 2020b, 73). ama özellikle de Roma İmparatorluk Dönemi'nde en görkemli halini yaşamıştır (Dupont-Sommer ve Robert 1964; Hild-Hellenkemper, 1990, 293 294; Sayar, 2000, 7-14; Ünal, 2006, 81-83; Kaplan, 2009, 90-96; Kurt, 2010, 486; Zeyrek, 2011, 96-116; Andrade, 2011, 123; Zeyrek, 2018, 21-32; Sayar, 2019a, 148; Sayar, 2019b, 334-355.). Roma İmparatorluk Dönemi’nde, MS ikinci ve üçüncü yüzyıllarda kentte sütunlu cadde ve anıtsal birçok yapı inşa edilmiştir (F. Krinzinger \& W. Reiter, Archäologische Forschungen in Hierapolis-Kastabala; şu yayında: G. Dobesh - G. Rehrenböck (edd.), Die epigraphische altertumskundliche Erforschung Kleinasiens: 100 Jahre Kleinasiatische Kommission der Österreichischen Akademie der Wissenschaften. Ergänzungsbände zu den Tituli Asiae Minoris nr. 14. Viyana 1993, 269-281.). Günümüzde Kastabala kentinde dağınık bulunan mimari parçalardan bile bu tür bir tespit rahatlıkla yapılabilmektedir (hem malzeme hem kütle hem de bezeme açısından). Geç Antik Çăğ’ın başlamasıyla, Hıristiyanlık ile birlikte tapımdaki tekilliğin kendine özgü kutsal yapıları da kentte inşa edilmiştir. $\mathrm{Bu}$ bağlamda kentte "Kuzey Kilise” ve "Güney Kilise” olarak adlandırılmış yapılar günümüzde kısmen korunagelmiş bir şekilde, kentin giriş kısmına yakın bir konumda, sütunlu caddelerle bağlamsal ilişki içerisinde (fig. 3, 9) ve birbirlerine neredeyse paralel olarak aynı aks üzerinde inşa edilmişlerdir (yaklaşık 300-350 m.) (Sayar, 2000, 11; Zeyrek, 2011, 104-105; Zeyrek, 2018, 57-60). Bu kiliseler kentin anıtsal yapılarına (blok, başlık, kaide, aedicula ve pilaster gibi) ait ve yerel taş ocağında kesilmiş kireçtaşı bloklardan oluşan mimari öğelerin yeniden kullanılmaları ile inşa edilmiştir (İmparatorluk Dönemi tapınağı, heroon, propylon?). Antik Coğrafyada, Hıristiyanlık ile birlikte Yunan ve Roma anıtsal dinsel yapıları ya kiliseye dönüştürülmüş (Öğüş, 2019, 85-98). veya sökülerek (bazen tamamen yakılıp tahrip edilerek) 
malzemelerinden kamusal ama özellikle de anıtsal dinsel kütleler inşa edilmiştir (Niewöhner, 2018, 243-264). Bu edim Kilikia için de geçerlidir. Özellikle bölgenin Trakheia kısmında bu dönüşüm özel bir küme oluşturmuştur (Ceylan, 2003, 73-82; Elton et al. 2007). Sonuçta bu geniş bölge, Kilikia, Pavlus’un kültürel topografyasıdır.

Kuzey Kilise adı verilmiş mimari kütle hem "paradoksal mimari” kısmen "adli mimari”, hem de "dekonstrüksiyon", konstrüksiyonun gerçekleştirildiği arkitektonik uzam da "genius loci” kavramları açısından büyük önem taşımaktadır. Biz “dekonstrüksiyon” ve inşa evrelerini ayrıca post-yapısalcı eleştiri üzerinden de "çevirmek" istiyoruz.

Kuzey Kilise, malzemenin kullanım kronolojisi açısından dönüşümsel bir tekrar inşa faaliyetidir (fig. 2, 4-6). Antik mimaride yapı bloklarının ve malzemelerinin kullanıldıkları işlev açısından belirgin terminolojik isim ve amaçları vardır. Normal bir inşa faaliyetinde kaideler, sütunlar, başlıklar, alt yapı, duvar ve üst yapı öğeleri, statik, gelenek, işlev veya estetik açıdan bir düzen oluşturarak (paradigmik yapı - mimari düzen) bulunmaları gereken yerde konumlandırılırlar. Form ve konumlarına uygun terminolojik isimler alırlar. Ancak Kuzey Kilise bağlamında bu tekrar inşa (ve oldukça pragmatik bir inşa) paradoksal bir hüviyet kazanmıştır. Bunun nedeni blokların ve inşa malzemesinin normalde kullanılması gereken yerlerde kullanılmayıp hatta neredeyse bir tersine inşa düzeninde kullanılmış olmalarıdır. Kuzey Kilise'nin kısmen de olsa en iyi korunagelmiş kısmı apsis façadı'dır (fig. 4-5). Kilisenin apsis bölümünün dış cephesinde, yer seviyesinden itibaren karşılaştığımız ilk öğe üç fascia’lı İonik bir arkhitrav bloğudur. Antik mimaride arkhitrav blokları sütunların üst seviyesinde konumlandırılırlar. Arkhitrav üzerinde astragal, İon kymationu ve sarmal bezemeler çalışılmıştır. Arkhitrav bloğunun üst seviyesinde Attik-İon kaide bloğu konumlandırılmıştır. Yani bir entablature parçasının üst seviyesinde kaide bloku bulunmaktadır. Daha sonra üst üste iki taş bloğu yerleştirilmiştir. Yukarıya doğru daha sonra birinin yaklaşık yarısı korunagelmiş üç kemer oluşturulmuştur. Kemerlerin konumlandırıldığı cephe apsis'in cephesi olup, kemer ayakları Korinth sütun ve pilaster başlıklarına oturmaktadır. Orijinal başlıklar bir anlamda kaide olarak kullanılmışlardır. Başlıklar çift kat akanthus yaprakları, volütler ve rozetlerden oluşturulmuştur. Her kemerde dokuz adet kemer taşı vardır. Tüm façade üzerinde toplam beş adet başlık vardır. Kemerler, kilit taşı dâhil dokuz taş bloktan oluşturulmuş haldedir. Kemerlerin üzerinde üç adet taş blok sırası bulunmaktadır. Taş blokların üst seviyesinde yeniden bir kaide dizisi sıralanmıştır. Kaidelerin üzerinde de orthostat blokları konumlandırılmıştır. Normalde stylobates seviyesinde bulunan orthostatlar yapının en üst seviyede bulunan mimari öğeleri olmuş durumdadır. Yapı en üst seviyede orthostat bloklarına değin korunagelmiştir. Çatı sistemi korunagelmemiştir. Çatı/ kubbe sisteminin orthostat bloklarına oturduğu ancak tahrip olduğu anlaşılmaktadır (fig. 5-7). Topografya üzerinde yapı bloklarının dağılımına baktığımızda, insan tahribatının yanı sıra bölgenin ileri düzey sismik seviye göstermesinin bir sonucu olabileceği hipotezini 
çıkartabiliriz. Genel olarak, devşirme mimari malzemenin süsleme bağlamında MS ikinci yüzyılın ikinci yarısına, büyük oranda da son çeyreğine ait olduğu tespit edilebilmektedir (Sayar, 2000, 10; Türkmen, 2007, 58-59; Kaplan, 2009, 94; Zeyrek, 2011, 96-105; Zeyrek, 2018, 41-43, 59-60). Söz konusu malzemelerden bir kısmının üçüncü kez kullanıldığ1 ve her kullanımda dönüştürüldüğü arazi çalışmaları esnasında tespit edilmekle birlikte bu önemli detay ve plastiğin tarihlendirilmesi makalenin konusunu aşmaktadır. Kuzey Kilise ise MS 5-6. yüzyıllara tarihlendirilmektedir (Sayar, 2000, 11; Zeyrek, 2011, 104-105; Zeyrek, 2018, 58-60; Sayar, 2019a, 147-148; Sayar, 2019b, 334-355; Sayar, 2020b, 73-82.). Daha sonra Kastabala'da ve Kilikia Bölgesi'nde bir süre için barbarların istilaları başlamaktadır. Tarihsellik içinde barbar istilalarının sonuçlarının en temel ortak noktası, var oldukları topografyalarda kültürel üretimin durması veya gündelik yaşamı sürdürme odaklı primitif seviyelerde yaşanmasıdır (büyük oranda ideolojik, siyasal ve ekonomi-politik üretimlerin durması gibi). Tıpkı Phryg Dönemi’ni sonlandıran Kimmerler, başta İonia olmak üzere bilinen dünyanın en yüksek kültürünü yerle bir eden Persler, Levant ve Anadolu'nun güney sahilleri coğrafyalarındaki salt yıkımsal içgüdülü fetihler yapan Araplar örneklerinde olduğu üzere. Sistematik bir yapı ve kültür üretemeyenin praksisi yıkma edimi üzerinedir.

Geç Antik Dönem'de devşirme malzeme kullanılarak inşa edilen veya onarımdan geçirilen kütlelerde kuşkusuz belirgin bir acelecilik, özensizlik ve rastgele inşa metodu kullanılmış olabilir (Niewöhner, 2018, 243-264). En azından bir dönüşüm hemen fark edilir. Ancak normalde stylobates düzleminde konumlandırılan orthostatların entablature'ün en üst seviyesinde (fig. 5-6) düşünülmeleri (muhtemelen çatı/kubbe sistemini sağlam bir blokajın üzerine oturtmak için), sütun ve pilaster başlıklarının kemer ayağı olarak kullanılmaları, arkhitravların en alt seviyede kullanılmaları ile oluşturulmuş pragmatik dizilim, bilinçli yapılmamış olsa dahi paradoksal mimari bağlamında dikkat çekici bir uygulamadır. Sonuçta pragmatik de olsa bu edim başka bir özgün dizge oluşturmuştur (aynı sözcüklerle başka bir cümle oluşturulmuştur). Mimari malzemelerin Kuzey Kilise inşa edilirken ikinci kullanımları (bazılarının üçüncü), malzemelerin paradigmik düzen anlamında tüm anlamsal ve dekoratif özelliklerinin yitirilmesine neden olmuş, malzemeyi düzenli bir yapının öğesi olmaktan çıkarıp onları dominant özellikleri sadece statik düzenin bir parçası olarak konumlandırmıştır. Bununla birlikte kemer, tonoz, harç kullanan mimari uygulamada statiğin pek de başarılı olamadığı kütlenin günümüzdeki durumu nedeniyle ortadadır.

Kuzey Kilise, malzemesinin üretim ve üretime yönelik kullanım amacının tamamen dışında olan bir anlayışla kullanılmasıyla inşa edilmiştir. Malzemeler üretilme amaçlarını tamamen (işlev, konum, süsleme) kaybetmiştir. Diğer bir ifadeyle malzemeler isimlerini, işlevlerini ve anlamlarını kaybetmişlerdir. Orijinal yapı ve/veya yapıların anlamları sökülmüştür. Bir taş bloğu arkhitrav olarak kullanılacaksa arkhitrav olarak kesilir, yontulur, çalışılır, üretilir. Arkhitrav haline getirildikten sonra o mimari parça artık düzensiz bir taş bloğu değildir. 
Arkhitrav haline getirildikten sonra terminolojik bir ismi olur, bu isimle anlam zincirine dâhil edilir, kültürel bir öğe olur. Zaman içinde değişir, gelişir, etkileşim yönünün ve mimari sürekliliğin bir parçası olur. Bu kültürel öğenin formu, bezemeleri bize onu tanımlayabilecek ve tarihlendirebilecek izler bırakır. Bu izler (sabit anlam göstergeleri), artık orada olmayan ancak bir dönem o kültürel topografyada var edilmiş kütlelerin (anıtsal kütlelerin) özgün doğalarına yönelik bir okuma yapabilmemize olanak verir. Doğası gereği “sabit anlamın” en dogmatik üretimi olması gereken dinsel bir kütlede (üstelik "tek tanrı" tekilliğinin ürettiği dinsel bir kütlede), malzemenin tüm düzensel (yapısal) anlamının kaybedilmesine neden olunması buradaki başlıca paradoksal inşa uygulamasıdır. Bu paradoksal inşa uygulamasının sahip olduğu içkin çelişki ise, sökülmüş mimari parçalarla oluşturulmuş yeni dizgenin sistematik bir inşa olmasıdır. Öğelerin terminolojik mimari isimleri baki kalsa bile anlamları kaybolmuştur. Anlamları kaybolmuş malzemeler ile düzenli bir inşa fiili gerçekleştirilmiştir. Yani gördüğümüz anda plan tipolojisinden ve görünümünden (temel unsurları nedeniyle) Kuzey Kilise'nin bir kilise, anıtsal bir kilise olduğunu anlayabiliriz (fig. 2-3, 7, 10). Bu durum, bu yeni inşanın sistematik ve düzenli yapısı, paradoksal inşanın içindeki içkin çelişkidir. Diğer taraftan bir kilise yapısının kilise yapısı olduğunu gördüğümüz anda anlayabiliyorsak nasıl bir çelişkiden bahsediyor olabiliriz? Mimarinin en temel ön kabullerinden birisi, Venturi’nin deyimiyle tamamlanmış bir üründe çelişki olmadığı düşüncesidir. Tamamlanmış bir ürün somut veya soyut bir modelin (bir kökenin, bir paradigmanın, düzenli bir yapının) kopyası, sürekliliğidir. Ancak Derridaryen söylem bize her zaman başlangıçtan itibaren bir "ek" inşasını gösterir. Bu durum bütünsel anlayışın sürekli değişimine işaret etmektedir. Diğer bir ifadeyle tamamlanmış bir yapı bulunmamakta, tamamlanması ertelenmiş yapıların ise sürekli bir biçimde farklı kümelerin geçici üyeleri oluyor olmaları düşünülmektedir. Bizim postyapısalcı ilk çevirimiz bu ikili üretim doğrultusuna dikkat çekmek bağlamındadır. Sistem her zaman çelişkilerden yararlanır (Akay, 2016b, 82). Kastabala kentinde konumlandırılmış Kuzey Kilise kütlesi (tıpkı Güney Kilisede de olduğu üzere) çifte paradoksal bir inşadır. Genellikle bu anlamda kullanılmasa bile, sismik bir doğal fenomenin Roma İmparatorluk Dönemi inşa mühendisliği sonucu oluşturulmuş anıtsal bir kütle üzerinde yarattığ tahribi gözlemleyebilmek, onu "Adli Mimari” olarak isimlendirilmiş adli/mimari tahribat formu kümesinin altında küçük bir kesişim kümesi olarak tanımlayabilmemize olanak verir düşüncesindeyiz. Malzemelerin söküldükleri kütle/kütleleri saptayabilmek, bilimsel kazılar yaparak üzerlerindeki tahribatı ve inşa/söküm evrelerini saptayabilmek, uzamsal bağlamda adli mimari noktasında yeni söylemler üretilebilmesine olanak verecektir. Kastabala araştırmaları henüz bu bağlamda bilimsel bir sonuç vermemiştir.

Kuzey Kilise'yi oluşturmuş inşa fiili anıtsal yapı/yapılardan devşirme malzemenin kullanılmasıyla gerçekleştirilmiştir. Peki, bu devşirme malzeme nereden sökülmüştür? 
Kastabala kenti üzerine yapılan arkeolojik ve teorik çalışmalarda Kuzey Kilise'nin doğusunda ve aynı aks üzerinde iki teras düzenlemesi ve bu teraslar üzerinde de kamusal ve dinsel majör kütleler önerilmiştir. Teorilerdeki en dominant öğe Artemis Perasia tapınağıdır. Artemis Perasia tapınımı (Dupont-Sommer ve Robert 1964; Sayar, 1999a, 142, 147-150; Pohl \& Sayar 2004, 107-11, bu kadim Anadolu Ana Tanrıçası'nın Yunan Dönemi’ndeki Anadolu formu, Kastabala kentinin dominant dinsel öğesidir ve Antik kent Hierapolis sıfatını kazanmışsa Anadolu Artemis'i üzerinden kazanmıştır. Hatta vasal kral Tarkondimotos'un, Anadolu Ana Tanrıçası, Kubaba, Kybele, Artemis, Magna Mater olarak bilinen tanrıça üzerinden Romanizasyon öncesinde bölgenin Hellenizasyonunu sağladığı bile önerilebilmiştir (Andrade, 2011, 123). Bununla birlikte kesin olarak hem mimari malzeme hem de epigrafik/ kontekst malzeme açısından bir kesin kanıta ulaşılmamış olunmasıdır. Ancak Kuzey Kilise'nin hemen doğusundaki ilk teras alanı aynı zamanda diğer kamusal anıtsal kütleler için de önerilmekte olan bir uzamdır. Diğer teras alanı aynı aks üzerinde tiyatronun doğusundaki düzenlemedir. Ancak buradaki uzamda sadece Artemis Perasia tapınağı önerilmektedir. Bunun nedeni uzamın bir temenos görünümü veren izole bir parergon çizmesi ve epigrafik kontekstin ağırlıklı olarak burada korunagelmiş olmasıdır (Krinzinger \& Reiter 269-287 ve içinde kent planı; Sayar, 2000, 10). Bu durum aşağıda açıklamaya çalışacağımız üzere bizce Norberg-Schulz'un “Genius Loci”, "Yerin Ruhu” kavramının da önemli bir örneğidir. Artemis Perasia (Dupont-Sommer ve Robert 1964, 13-14, 33; Hild \& Hellenkemper 1990, 293-294; Sayar, 1999a, 142, 147-150; Sayar, 2000, 10; Pohl \& Sayar 2004, 107-118; Zeyrek, 2011, 107; Andrade, 2011, 123-129; Zeyrek, 2018, 84-87 (detaylı bibliyografya için bkz. 8487 arası dipnotlar)) tapınımı Kastabala kentinin Hierapolis olarak adlandırılmasının en temel nedenidir. Çatalhöyük, Hacılar, Höyücek ve diğer majör arkeolojik alanlardan bildiğimiz Anadolu Ana Tanrıçasının kadim geleneğinin işaretleri olan Artemis, Aphrodite gibi bazı Eski Yunan tanrıçalarının Anadolu'daki kültleri tapınım gördükleri uzamların hiyerarşilerini değiştirme gücü göstermiştir (Okan, 2019, 44-55, 100-108, 169-177). Bu durum Menderes Magnesia's1, Sardes, Ephesos, Ankyra, Aphrodisias, Pessinus, Perge gibi Antik alanlardan bilinmektedir (Kortanoğlu, 2018a, 26, 113-116; Kortanoğlu, 2018b, 397-398; Kortanoğlu, 2019, 281-290). Ancak mutlaka göz önüne alınmalıdır ki eğer mimari parçaların bir kısmı bile Artemis Perasia Tapınağı'ndan alınmışsa, bu durum MS ikinci yüzyılın son çeyreğinde ya tapınağın büyük çaplı bir onarımdan geçirildiğini veya bu tarihte ikinci kez (?) inşa edildiğini gösterir. Diğer seçenek ise kentin giriş bölümünde konumlandırıldıkları düşünülen özenli cephe mimarisine sahip anıtsal dinsel/kamusal yapılardır (Roma İmparatorluk Dönemi tapınağı, Heroon, Propylon gibi).

Bu noktada Bourdieu'nün “Alan” kavramı üzerinde ayrıca bir parantez açmak istiyoruz. Bourdieu'nün Alan kavramı, onun pratikler kuramının, kültür ve toplumsal yapı arasındaki ilişkileri nasıl kavramsallaştırdığını göstermektedir (Swartz, 2018, 15). Bourdieu, toplumsal varoluşun toplumsal, kültürel ve ekonomik gibi kesitlere ayılabileceği ve birbirinden ayrı 
alanlar halinde hiyerarşik olarak düzenlenebileceği fikrine karşı çıkmıştır (Swartz, 2018, 62). Üstyapının ve altyapının (bu iki alanın) ayrılamayacağını savunur. Bourdieu, toplumsal dünyayı, çeşitli maddi ve kültürel kaynak biçimlerinin üretildiği, dolaşıma girdiği ve tüketildiği alanlar olarak kavramsallaştırır (Swartz, 2018, 63). Pavlus'un mirasının ağır yükünü taşıyan Kilikia halklarının, Milano Sözleşmesi ve İznik Konsülünün ardından ve Roma İmparatoru'nun (hâlihazırda pagan bir tanrı olan imparatorun (Sayar, 1999a, 151) tek tanrı karşısında düşürüldüğü yeni konumu kabul etme süreci) Hıristiyanlığı kabul etmesi (etmek zorunda kalması) ile birlikte hızlı bir dinsel mekân üretimine (dönüştürme ve inşa edimlerini kapsayan) başlaması bu bağlamda kaçınılmazdır. Kastabala'nın ikiz kiliseleri de Bourdieu'nün Alan kavramında betimlediği tür bir üretimin nedeni, öğesi, sonucu ve mirasıdırlar. Antik Kastabala kentinde bu sosyo-kültürel üretim metodunu Artemis Perasia tapınımı ve anıtsal kütlesi başlatmıştır. Fakat binlerce yıldır bu toprakların sahibesi olan bu kadim tanrıçanın, salt bölgenin Hellenizasyon ve Romanizasyonu için uyandırılmış sıradan bir dinsel figür olabileceğini düşünmüyor, sadece tanrıçanın binyıllardır bilinç dışında yer etmesinin, dinsel gücü ve toplumsal rolünün bir hegemonik iktidar ilişkisinin altyapısı bağlamında kullanılmak istenmesinin potansiyelini kabul ediyoruz.

Özellikle ilk teras alanının (Kuzey Kilise'nin hemen doğusundaki uzam) Perasia kültü için bir potansiyel taşıdığını kabul edilirse, Norberg-Schulz'un "genius loci - yerin ruhu" kavramı Kastabala kenti için ilginç bir niteliğe bürünmektedir (Norberg-Schulz, 1979). Çünkü Kuzey Kilise teras alanının hemen batısına, kuzey sütunlu caddenin hemen bitişiğine inşa edilmiştir. Genius loci kavramını tapınağın muhtemel iki konumu açısından tartışabiliriz. Ancak genius loci kavramını Bourdieu'nün alan kavramı çerçevesinde değerlendirirsek tüm kentin bir parergon halini aldığını ve artık Kastabala’nın Hierapolis Kastabala olma potansiyelinin somutlaşmasına olanak sağladığını saptayabiliriz. Kült alanlarının seçilme kriter ve hiyerarşileri çok erken dönemlerden itibaren (Erken Bronz Çağ) tapınım için seçilmiş olan uzamın (sınırlandırma) kişi ve topluluk üzerinde uyandırdığı özel etki (ruhani - ilham veren) ile doğru orantılı olmuştur. Latince Genius Loci (= bir yerin hissi koruyucu ruhu) kavramı bir uzamı (sınırlandırılmış çerçeveyi) anlamlandıran sezgisel bir terimdir. Belirgin bir farklılık ve farkındalık yaratır ki Norberg-Schulz bu durumu Delphoi, Atina, Selinus ve Syrakusai gibi dinsel, anıtsal ve öne çıkan örnekler üzerinden açıklamaya çalışmıştır (Norberg-Schulz, 1979). Dinsel tapınım sürekliliği bağlamında bu konuda Anadolu'daki en önemli örneklerden bir tanesi Ankyra'daki Roma-Augustus tapınağıdır (Kybele-Men) (Akurgal, 1987, 126-127; Spawforth, 2006, 218; Kortanoğlu, 2018, 118). Kastabala'da da kentin kuruluşundan itibaren veya diğer bir ifadeyle yerleşimin Eski Yunan kenti haline gelmesinden itibaren, ana tanrıça tapınımı en dominant dinsel karakter gösteren, hiyerarşide en yukarıda yer alan bir öğedir (eğer elimizde tanrıçanın buradaki varoluşuna yönelik sikke dışı ikonografik veriler olsaydı metaforik hiyerarşisini de sosyolojik bağlamda saptamamız söz konusu olabilirdi). Bununla birlikte hiyerarşik olarak benzersiz bir seviyede tapınım ve 
saygı gören ana tanrıçaya ait topografik uzamın ve kütlenin ikinci teras alanında, daha uzak ve özel bir alanda konumlandırılmış olması da bilimsel ve yerinde bir öneridir. Özellikle kırsal Hıristiyan toplumlarında kilise yapılarının yerleşimin çekirdeğine konumlandırılmaları günümüzde bile devam eden bir uygulamadır. İlk teras alanı yerleşimin çekirdeğine ve ana sütunlu caddeye oldukça yakın hatta bitişik bir uzamdır. Eğer kilisenin inşa edildiği devşirme malzeme tanrıçanın tapınağından değil de kentin anıtsal kamusal yapılarından sökülmüş ise daha farklı anlamda bir genius loci söz konusu olabilir. Belki de burası erken tapınağın konumlandırıldığı alandır. Ancak şüphesiz bilimsel sondaj çalışmaları yapılmadan bu konuda gerçekçi bir söylemde bulunulamaz.

\section{Kilikia'da Hıristiyanlığın Erken İzleri}

Kilikia Ovası'nın doğusunda kalan Hierapolis Kastabala antik kentinde erken döneme tarihlenen ve benzer plan tipine sahip iki kilise mevcuttur. ${ }^{1}$ Yerleşmenin terkedilmiş olması ve günümüzde üzerinde yerleşim bulunmaması kalıntıların büyük oranda korunmasını sağlamıştır.

Hierapolis adı verilen kentin, kutsal alanla ilişkilendirilen kimliği (Sayar, 1999, 200; Pohl \& Sayar 2004, 107-118), Artemis Perasia tapımı döneminden sonra da devam etmiş; Hıristiyanlığın bölgede yayıldığı dönemde kentte eşzamanlı iki kilise inşa edilmiştir. Bölgedeki nitelikli inşa faaliyetlerinden anlaşıldığı üzere, kentin farklı dönemleri arasında Roma İmparatorluk Dönemi öne çıkmaktadır (Sayar, 2019a, 147-149; Sayar, 2019b, 334355; Sayar, 2020b, 73-82). Kentte pagan gelenekten Hıristiyanlığa geçiş sürecinde inşa edilmiş iki kilise bulunması kentin nüfuzlu konumunu Erken Hıristiyanlık Dönemi’nde de sürdürdüğünü kanıtlar.

Kilikia'nın Hıristiyanlıkla bağlantısı Havariler Dönemi’ne yani birinci yüzyıla kadar götürülebilmektedir. Hıristiyan geleneğin örgütlenmesinde büyük önemi olan Havari Pavlus, kendisini “Kilikya'dan Tarsuslu bir Yahudi” olarak tanıtır (Elçilerin İşleri, 21:39) ve Galatyalılara Mektuplar bahsinde Yahudi dininden Tanrı'nın Kilisesi olarak adlandırdığı İsa Mesih yoluna geçişini anlatırken, Suriye ve Kilikia bölgelerine gittiğinden bahseder (Gal.1:13, 21). Pavlus'un Suriye ve Kilikia bölgelerini dolaşarak inanan topluluklarını ziyaret ettiği (Elçilerin İşleri, 15:41) ifadesi, bu bölgelerdeki toplulukların örgütlenmesi anlamında Pavlus'un bölgedeki kiliselerin kurucusu olduğuna işaret eder. Hıristiyan

1 Hierapolis Kastabala Kiliseleri'nden ilk kez E.J. Davis'in 1879 tarihli yayınında bahsedilir; T. Bent'in 1890 tarihli yayınında ise kiliseler kent planında belirtilir (Davis 1879, 131; Bent 1890, 234). R. Heberdey ve A. Wilhelm, 1896'da Güney Kilise'nin planını yayımlar, 1906'da Gertrude Bell her iki kiliseyi de tanımlar ve Kuzey Kilise'nin planını yayımlar. Dupont-Sommer ve Robert'in 1964 tarihli yayınında Hierapolis Kastabala'nın Hıristiyanlık öncesi kült tarihi anlatılır ve kiliselerin fotoğrafları yer alır (Heberdey-Wilhelm 1896, 25; Bell 1906, 4, fig. 1; Dupont-Sommer ve Robert 1964, levha XVIII). 1986'da O. Feld, önceki yayınların 1şığında ve alanda yaptığı çalışmaların sonucunda Kuzey ve Güney Kilise'yi yeniden değerlendirerek her iki kilisenin planını ve Kuzey Kilise'nin apsis çizimini yayınlar (Feld 1986, 77-86). 
gelenekte bu ifadelere dayanılarak İsa'nın ardından Hıristiyanlığın ilk örgütlenmesinin Kilikia'da gerçekleştiği, Anadolu'da Hıristiyan topluluklarının ilk izlerinin Kilikia'da olduğu düşünülmektedir. Hac Yolu² üzerinde olan Tarsus, Adana ve Mopsouhestia (Misis) Pavlus'un Hıristiyan cemaati örgütlediği kesin olarak bilinen kentler arasındadır. Soli ve Anazarbos ile kuzeyden güneye inen Roma yolları güzergâhında önemli bir konumda yer alan ve Hac Yolu'nun yakınında konumlanan ve piskoposluk merkezlerinden biri olan Hieropolis Kastabala da Pavlus dönemi kilise yapılanmasında etkin olması muhtemel merkezlerdendir (Wilson, 2003a, 14; 2003b, 96).

Pavlus'un Kilikia kentlerinde yapılandırdığı muhtemel "Hıristiyan topluluk/kilise"ler, kendisinin misyonerlik yolculuklarına başlamadan önceki dönemine, Hıristiyanlığı kabul ettiği MS 33 ile misyonerlik yolculuklarından ilkine başladığı MS 47 yılları arasındaki döneme aittir. ${ }^{3}$ Kilikia'da Hıristiyan topluluklarının Pavlus'un İncillerde geçen misyonerlik faaliyetlerinden öncesine tarihlendirilmesi, Kilikia'nın Erken Hıristiyanlık tarihindeki yerine dair önemli sonuçlara yol açar. Bunlardan ilki, Kilikia topluluk/kiliselerinin; Elçilerin İşleri kısmında geçen ilk kilisenin Antakya'da (Antiocheia ad Orontes) kurulduğuna ilişkin verileri öncelemiş olmasıdır. ${ }^{4}$ Benzer şekilde Pavlus'un ilk misyonerlik yolculuğunda ziyaret ettiği Galatia ve Pisidia Antiocheia'sı bölgelerinde kurulan toplulukları da önceleyerek, Anadolu' da kurulan ilk Hıristiyan topluluk anlamında "kilise" olarak Kilikia cemaati karşımıza çıkar. ${ }^{5}$

Kilikia bölgesi erken dönem piskoposluk listelerinde Cilicae Primae (metropolitlik merkezi Tarsos) ve Cilicae Secundae (metropolitlik merkezi Anazarbos) olarak ikiye ayrilır (Hild \& Hellenkemper 1990, 39). Cilicae Primae'da sekiz, Cilicae Secundae'da on olmak üzere Kilikia'da toplam on sekiz piskoposluk merkezi bulunmaktadır. Bu listelerde Kastabala, Ecclesia Castabalorum başlığı altında verilmiştir. ${ }^{6}$

2 Antik kaynaklarda Hac Yolu; Itinerarium Burdigalense, Itinerarium Antonini seyahatnamelerinde ve Tabula Peutingeriana haritasında geçer. Hac Yolu'nun Anadolu rotası Kalkedon'dan Tarsus'a ve oradan Suriye Antiocheia'sına uzanır. Bordeaux'dan Kudüs'e uzanan rotayı tarif eden Itinerarium Burdigalense; Chalcedon, Nicomedia, Ancyra, Tarsus ve Suriye Antiocheia'sını merkez alarak aralarındaki hac yerlerini tanımlar (French 2016, 15, 17, 25, harita 4b). Tabula Peutingeriana haritasına göre D. French tarafından oluşturulmuş güncel haritada önemli merkezler numaralandırılmıştır. Bu haritada 67 no'lu lokasyon olan Epiphania (Erzin) ile Kastabala arası 19 km.' dir. Bu haritalardan anlaşıldığı üzere Kastabala, hac güzergâhında önemli lokasyonlara çok yakındır.

3 Pavlus'un bu dönemiyle ilgili ayrıntılı bilgi için bk. Hengel ve Schwemer 1997.

4 Bu bağlamda İncillerde birbiriyle çelişebilen sonuçlara yol açabilecek ifadeler mevcuttur. Çünkü her iki iddia da kaynağını Elçilerin İşleri bahsinden almaktadır.

5 İkincisi, bu varsayıma göre Kilikia kiliselerinin zaten örgütlenmiş olması, Pavlus'un misyonerlik rotasının sonraki aşamasında yönlendirici olmuştur. İncillerde Pavlus'un ilk yolculuğu havari Barnaba'yla birlikte Seleukeia Piereia, Kıbrıs ve Perge rotasında anlatılır (Elçilerin İşleri 13:4,13). Son olarak, Kilikia topluluk/ kiliseleri diğerlerini önceliyorsa; bu kentlerdeki Romalı ve Yahudi topluluklarıyla yaşadığı deneyimin, Pavlus'un sonraki misyonerlik faaliyetlerinde yardımcı olduğu çıkarımını yapmak mümkün olacaktır (Wilson 2003a, 15-6).

6 Kilikia eyaletleri piskoposluk listeleri için bk. Quien 1958, 869-908; Honigmann, 1939, 46; Kastabala için bk. Quien 1958, 901-902; Hild - Hellenkemper 1990, 293-294. 
Beşinci yüzyılda Doğu Roma İmparatorluğu önemli dönüşümler geçirir. Dördüncü yüzyıldan itibaren idari ve toplumsal anlamda kurumlarını Hıristiyanlığa uyarlayarak varlık gösteren İmparatorluk ${ }^{7}$, dördüncü yüzyıl ile dokuzuncu yüzyıl arasında toplam yedi ekümenik konsil düzenleyerek ${ }^{8}$ Hıristiyanlığın kurumsal yapılanmasında etkin rol oynar. İmparator Constantinus'un (306-337) dördüncü yüzyılda Hıristiyanlı̆̆ bırakması, kilise-devlet bütünleşme sürecini başlatan bir gelişmedir. Bu bütünleşme, en çok eyaletlerden gelen piskoposların oluşturduğu kilise konsillerinde görülür (Kaçar, 2003, 119). Dördüncü yüzyılda Kilikialı piskoposların hem yerel hem de merkezi kilise politikalarında önemli rolü olduğuna dair veriler bulunmaktadır. ${ }^{9} \mathrm{Bu}$ dönemde toplanan yerel konsillerde Kilikialı piskoposların adına sıklıkla rastlanır. İlk ekümenik konsil olan ve I. Constantinus başkanlığında toplanan İznik Konsili’ne (325) katılan piskoposlar arasında Kilikia'nın farklı bölgelerinden on piskoposun yanı sıra Kastabala'dan Moses da yer alır (Honigmann, 1939, 46, no. 81). Aynı isim, Antakya Konsili’nde (341) karşımıza çıkar. Yerel konsillerden biri olan Lampsakos Konsili'ne (364/366?) katılanlar arasında Kastabala'dan Theophilos ismi geçer (Kaçar, 2003, 126).

Kilikia ve Isauria'da bu döneme tarihlendirilen pek çok kilisenin varlığı arkeolojik verilerin yanı sıra yazılı kaynaklardan da bilinmekte ${ }^{10}$, yapılan yüzey araştırmalarında yeni kiliseler bulunmaya devam edilmektedir. ${ }^{11}$ Bölgede Geç Roma Dönemi’ne, özellikle beşinci ve altıncı yüzyıllara tarihlenen kiliselerin sayısının dikkat çekici olmasında bölgenin bu dönemde refah seviyesinin yüksek olmasının ve İmparatorluk desteği görmesinin etkisinden daha da önemli olanın Hıristiyanlığın güçlü etkisi olduğu düşünülmektedir (Elton, 2013, 246).

7 Konuyla ilgili detaylı bilgi için bk. Duygu 2017, 191-2.

8 Bu dönemde ekümenik boyutta toplam sekiz konsil gerçekleşmiştir. Ancak sekizinci konsilin niteliği hakkında Katolik Kilisesi ile Ortodoks Kilisesi arasında tartışma vardır. Konu ile ilgili bk. Yalduz 2003, 266. Konsiller ile ilgili ayrıntılı bilgi için bk. Dvornik 1990.

9 Dönem kaynaklarında yerel piskoposların teolojik tartışmalar üzerinden süregiden iktidar mücadelesinin örneklerine rastlamak mümkündür. Tarsuslu Silvanus'un Theophilus'u Kastabala piskoposluğuna atamasıyla yaşanan sorunlar bunlardan biridir. Dördüncü yüzyılda Kilikialı piskoposların kilise politikasındaki etkileri hakkında ayrıntılı bilgi için bk. Kaçar 2003.

10 Kilikia ve Isauria bölgeleri birbiriyle yakın ilişkili ve kimi zaman sınırları iç içe geçmiş bölgelerdir. Roma döneminde Kilikia, Kilikia Pedias (Ovalık Kilikia) ve Kilikia Tracheia (Dağlık Kilikia) olmak üzere iki farklı eyalete ayrılır. Dağlık Kilikia, Diokletianus döneminde (284-305) idari düzenlemelerle Ovalık Kilikia'dan ayrılmış ve metropolitliği Seleukeia olmak üzere ayrı bir eyalet statüsü kazanmıştır (Hild ve Hellenkemper 1990, 34) Konuyla ilgili yayınlarda bu bölgelerin adlandırılmaları ve sınırlarının kapsamıyla ilişkili olarak farklı tercihler olmakla birlikte genel saptamaların her iki bölgeyi de kapsadığı görülmektedir. Isauria için yapılan kimi çalışmaların sonuçları, Kilikia için de açıklayıcı ve geçerli bulunarak bu çalışmada kullanılmıştır. Nitekim çoğu kez Dağlık Kilikia ile Isauria bölgelerinin aynı alanı kast etmek üzere kullanıldığı görülmektedir.

11 Göksu Arkeoloji Projesi (GAP) kapsamında Isauria'da 2002-2006 arasında gerçekleştirilen yüzey araştırmalarında 19 yeni kilise saptanmıştır. Bölgede kaç kilise olduğunu tam olarak saptamak mümkün olmamakla birlikte eldeki verilerden hareketle ortalama bir hesap yapıldığında altıncı yüzyıl itibarıyla Isauria'da 1100 civarında kilise olduğu tahmin edilmektedir. Dönem kaynaklarında da bu saptamayı doğrulayacak veriler yer alır (Elton 2013, 233-4). Ovalık Kilikya'da geç antik dönem yerleşim yerleri ve kiliseleri hakkında bkz. Sayar 2020a, 53-59. 
Isaurialılar, dağlık yapıya sahip zor bir coğrafyanın sert tabiatlı halkı olarak askeri becerileri ve taş işçiliğindeki ustalıklarıyla bilinirler (Gough, 1972, 199). Beşinci yüzyılda Isauria kökenli Zeno'nun (474-475/476-491) imparator olmasıyla Isaurialıların Doğu Roma İmparatorluğu'ndaki etkileri, Zeno'nun iktidara ikinci kez gelişinden sonra ise Kilikia ve Isauria'daki imar faaliyetleri artar. ${ }^{12}$

\section{Hierapolis Kastabala Antik Kenti Kuzey ve Güney Kiliseleri}

Roma İmparatorluğu'nun beşinci yüzyılda geçirdiği sosyo-kültürel dönüşümün izleri Hierapolis Kastabala'da da görülür. Kentte bu döneme tarihlenen iki anıtsal Hıristiyan yapısı bulunması, Hıristiyanlığın bölgede oldukça etkili olduğunu gösterirken; bu yapılarda devşirme malzeme kullanımının oldukça fazla olması aşamalı olarak gerilemeye başladığının bir göstergesi olarak okunabilir (Hill, 1996, 104).

Hierapolis Kastabala kiliseleri yerleşimin kurulu olduğu vadinin iki farklı bölgesinde yer alır ve kent planındaki konumuna göre Kuzey Kilise ve Güney Kilise olarak adlandırılırlar. Yapıların özgün adları ve hamileri bilinmemektedir. Sütunlu Yol'a paralel konumlanan Kuzey Kilise ile yol arasında yaklaşık beş metre mesafe vardır. Kiliseye batıdan erişim, yolun kenarındaki sütun dizisinin hizasında bulunan portal ile sağlanmaktayd1.

İki kilisenin plan tipi, apsis biçimleri, malzeme ve teknik özellikleri birbiriyle benzerlik gösterir. ${ }^{13}$ Her iki kilisenin de günümüze gelebilen büyük kesme taş bloklarla örülü doğu cephelerinin kalıntıları bu benzerliği ortaya koyar. Kastabala kiliseleri büyük kesme taş kullanılarak inşa edilmiştir. Kilikia ve Isauria bölgelerinde küçük düzgün kesme taş kullanımı yaygın olmakla birlikte Kilikia'nın doğusuna gidildikçe büyük kesme taşın kullanıldığı örneklerin arttığı görülür. Bölge kiliselerinde, yapıların statik açıdan kritik kısımlarında özellikle apsislerinde, diğer kısımlarda kullanılandan daha dayanıklı malzeme (daha büyük taşlar gibi) kullanıldığı görülür. Bu durum, yapıların kalan bölümleri yıkılmış iken çoğunda apsislerin ayakta kalmasını açıklar (Hill, 1996, s. 12-3).

Erken Hıristiyanlık Dönemi kiliselerinin önemli bir kısmı bölgedeki mevcut tapınaklara bazı değişikliklerle yeniden işlev kazandırılmasıyla veya yapıların mimari malzemesinin yeniden kullanılmasıyla inşa edilmiştir. Hierapolis Kastabala Kuzey Kilise ve Güney Kilise de benzer şekilde devşirme malzemenin yoğun kullanıldığı örneklerdir.

12 Bölgede Zeno dönemine atfedilen kiliselerin tarihlendirilmesi ile ilgili tartışmalı görüşler olmakla beraber, bölgede yapım etkinliklerinin en parlak evresinin beşinci yüzyıl ortalarından Zeno'nun öldüğü 491 yılına dek olduğu, bilim çevrelerinde genel olarak kabul edilmektedir (Gough 1972, 199; Hellenkemper 1986, 63-90; Hill, 1996,6; Özyıldırım ve Yeğin 2019, 266).

13 Güney Kilise'nin planı için bk. Hellenkemper 1994, 233, 25) 
Hierapolis Kastabala Kuzey Kilise ve Güney Kilise dışında; Kilikia’da görülen benzer tapınak dönüşümleri arasında Diocaesarea (Uzuncaburç) Zeus Olbios Tapınağ1; Seleucia Ad Calycadnum (Silifke) Zeus Tapınağı; Elaiussa Sebastae (Ayaş) TapınakKilise; Korykos Tapınağı, Meryem Şapeli; Kanytelis (Kanlıdivane); Çatıören; Meryemlik Azize Tekla Makamı; Cambazlı; Dağ Pazarı Bazilika, Kubbeli Kilise; Olba (Ura) Kent Kilisesi; Epiphania (Erzin); Anazarbus Havariler Kilisesi; Flavias (Kadirli) örnekleri yer alır (Elton, 2007).

Traian, Hadrian, Caracalla gibi Roma imparatorları (aynı zamanda birer tanrı olan) Kastabala kentini ziyaret etmişlerdir. İmparatorluk kültünü simgeleyen heykel ve/veya kaideler ve tapınak bu hiyerarşik statünün göstergeleridir. Antik Hierapolis Kastabala kentinde, Artemis Perasia (Sayar, 1999b, 200; Pohl \& Sayar, 2004, 107-118) ve İmparatorluk Kültü dışında başka kültler de olsa, tapınımın ve yarattığı hiyerarşinin niteliği açısından bu iki kült, özellikle de İmparatorluk Roması'nda temel dinsel fundamentali oluşturmuştur. Biz bu durumun Hıristiyanlık tekilliğine, tek tanrı inancına geçişte büyük bir kolaylık sağlamış olabileceğine dikkat çekmek istiyoruz. Hıristiyanlığın tek tanrı düşüncesi doğal olarak MS 4. yüzyılın sonlarından itibaren kentin dinsel pratiğinde "tek" unsur olmuştur. Bu durumun nedeni anlaşılabilir, çünkü paradigma bütünüyle olmasa bile bütüne yakın bir şekilde ve kati olarak değişmiştir. MÖ Sekizinci yüzyıldan, Homeros'un dizelerinden itibaren Zeus dini, pagan bir din sistemi, Ege ve Doğu Akdeniz coğrafyasında temel yapının en görünür unsuruydu (Kortanoğlu, 2018a, 113-116; Kortanoğlu, 2018b, 397-398). Yaklaşık 12 yüzyıl (Roma dini ve tanrılarıyla beraber) paradigmik yapı (düzenli yapı, kültür) bu şekilde iktidar olmuş ve sürekliliğini sağlamıştır. Ancak artık tek Hıristiyan tanrının hâkimiyeti başlayınca, toplumsal, ideolojik, ekonomi-politik, sosyo-kültürel yapılar üzerinde Hıristiyanlığın kabul edilebilir, sürdürülebilir, aktarılabilir bir iktidar modeli ortaya koyması gerekmiştir. Özellikle Pavlus'un etkisi de düşünülürse bu modelin doğası gereğinden daha fazla konservatif praksisler göstermiş olması beklenebilir.

Kuzey ve Güney kiliseler devşirme malzeme ile inşa edilmiştir. Kentin Roma Dönemi'ne ait anıtsal malzemelerden yapılan kiliselerin hızlı bir şekilde inşa edildiklerini anlaşılmaktadır. Bu kiliseleri inşa etmek için dinsel ve/veya anıtsal kamusal yapıların sökülmesi Kastabala halkını kesinlikle rahatsız etmemiş görünmektedir. Onlar için önemli olan şeyin, düzgün zemin döşemelerine sahip sütunlu caddelerin hemen bitişiğinde, toplanma ve dağılma sirkülasyonları kolay olan, taş malzemeden kilise yapıları inşa etmek olduğu anlaşılmaktadır.

\section{Kuzey Kilise}

Kuzey Kilise, 33 x 17 m. boyutlarında, üç nefli, doğu-batı doğrultusunda uzunlamasına dikdörtgen bir bazilikadır (fig. 7-8, 10). Yapının orta nefi (naosu) doğuda çok kenarlı 
(poligonal) dışa taşkın bir apsisle sonlanır. Apsisin doğusunda ve batısında, yan neflerle ve apsisle bağlantılı köşe odaları yer alır. Nefler birer çift payenin taşıdığı geniş kemerlerle birbirinden ayrılır. ${ }^{14}$ Yapının üstünde günümüze gelememiş bir galeri katı vardır. ${ }^{15}$

Kuzey Kilise'de payelerin desteklediği kemer kalıntılarında tuğla kullanılmıştır. Bölgedeki sarnıç ve hamam yapıları dışında Kilikia'da özellikle kiliselerde tuğla kullanımı çok nadirdir (Hill, 1996, 11-12, 105). Kilikia ve Isauria'da poligonal apsis tipi beşinci yüzy1l ortasından itibaren görülmeye başlanır; Hierapolis Kastabala'daki Güney ve Kuzey Kilise, Diokaseria (Uzuncaburç) Tapınak Kilise, Azize Tekla Meryemlik’teki Zenon Kilisesi ile Ferhatlı Bazilikası bu tipe örnek yapılar arasında yer alır.

Erken Hıristiyanlık Dönemi Suriye ve Kilikia bölgesi kiliselerinde köşe odalarının işlevleri çeşitlilik gösterir. ${ }^{16}$ Çoğunlukla kuzey oda, bazı örneklerde de güney oda vaftiz odası olarak kullanılmıştır (Aydın, 2003b, 220). Hierapolis Kastabala kiliselerinde köşe odaları günümüze gelemediği ve alanda da in situ veri bulunamadığı için kesinlik taşımamakla beraber, bu yapılardaki köşe odalarından birinin vaftiz işlevi üstlenmiş olması olasılık dâhilindedir. Gough yapının kuzeyinde bir avlu olduğuna dair izler tespit etmiştir. Alanda sürdürülmekte olan kazılarda avlu, avludan kiliseye geçişi sağlayan merdivenler ve propylon ortaya çıkarılmıştır. Kilikia Bölgesi Erken Dönem kiliselerinde avlu yaygın değildir. ${ }^{17}$

Yapının mimari plastik malzemesinin neredeyse tamamı büyük oranda ikinci yüzyıla tarihlenen devşirme malzemeden oluşur. Bu malzemenin gösterdiği çeşitlilik göz önünde bulundurularak birden fazla yapıdan devşirme malzeme kullanıldığı düşünülmektedir (Hill, 1996,104; Bayliss, 2001, 200). Bu durumun tek istisnası apsisteki pencere açıklığında yer alan bir sütun başlığıdır. Korinth tipi başlığın volüt kısmının ortasında tavuskuşu olması muhtemel bir figür, abaküste ise bir çift yılan betimlenmiştir. Bu parça için öngörülen tarih, beşinci yüzyıldır (Hill, 1996, 104). Kuzey Kilise'de kullanılan Korinth tipi sütun başlıklarının benzerlerine alan içinde Sütunlu Cadde ve Agora/Macellum'da; alan dışında ise Perge güney

14 Bell'in planında payeler haç formludur (Bell 1906, 4, fig. 1).

15 Hill 1996, 104. Erken dönem kiliselerinde galeri katının liturjik işleviyle ilgili farklı görüşler mevcuttur. Galeri katının ayini izleyen kadın ve çocuklara veya henüz vaftiz olmamış bir topluluk olan ve dolayısıyla Ökaristi başlamadan kiliseyi terk etmesi gereken katakumen'lere ayrıldığı yönündeki görüşler için bk. Mathews 1977, 25-134. Kuzey Kilise'nin galeri katı olduğu bilinmekle birlikte, galeriye çıkan merdivenlerin nerede olduğunu saptamak mümkün değildir. Aynı döneme tarihlenen ve benzer mimari özellikler gösteren Batı Anadolu bazilikalarıyla ilgili çalışmalarda; atrium ve narteks bağlantılı merdivenler saptanmış, bu planlamanın Ökaristi öncesinde kiliseyi terk etmesi gereken katakumen'lerin galeriden diğerlerini rahatsız etmeden çıkabilmesini sağlamak için uygulanmış olabileceği ve bu durumun da katekumen liturjisinin Konstantinopolis ile bağlantılı olabileceği ileri sürülmüştür (Ceylan 2001, 195).

16 Ökaristi ayininde ekmek ve şarabın bemaya getirilmesine dair liturjinin dördüncü yüzyılda gelenekselleşmeye başlamasıyla bu yüzyıla tarihlenen Suriye kiliselerinde köşe odaları (pastoforion) görülmeye başlanır (Mathews 1977, 146).

17 Bölgede avlusu olan diğer kiliseler arasında Emirzeli 1 No.lu Kilise, Kanlıdivane 1 ve 2 No.lu Kilise, Tapureli A, B ve C Kiliseleri, Mersin Seyranlık Kilisesi yer alır (Aydın 2003b, 218). 
hamam girişindeki Propylon'da ve Soloi Pompeiopolis’teki Sütunlu Cadde'de rastlanmıştır. Yapının mimari plastik ögeleri, Geç Antonin - Erken Severus Dönemi özellikleri gösterir (Zeyrek, 2018, 57-60).

Yapının ölçüleri ve planı (fig. 8, 10) göz önünde bulundurulduğunda örtü sistemi açısından Helenistik Bazilika özelliği gösterdiğini söylemek mümkündür. ${ }^{18}$ Bölgedeki yapıların örtü sisteminde özellikle ana çatıda yaygın olarak ahşap ve pişmiş toprak kullanıldığı düşünülmektedir. ${ }^{19}$ Kuzey Kilise’nin boyutları (33 x 17 m.) ile Kilikia ve Isauria bölgelerindeki benzer yapılar karşılaştırıldığında bu yapıların örtü sistemleriyle ilgili benzer çıkarımlarda bulunmak mümkündür. ${ }^{20}$

Kilikia ve Isauria bölgelerindeki Erken Hıristiyanlık dönemi kiliseleri yerel özellikler yanı sıra, Suriye ve Konstantinopolis gibi merkezlerin de bazı mimari etkilerini yansıtır. Yerel özellikler içinde kiliselerin bazilikal planı, duvar örgüsü, kuzey cephede hava koşulları nedeniyle pencere açıklıklarına yer verilmemesi ve batıda narteksin üç arkadlı girişi sayılabilir. Kiliselerin doğusunda yer alan ortada bema ile kuzey ve güneyindeki birer yan odadan oluşan üç mekânlı düzen ve yan odalardaki galeriler Suriye kiliselerinin; narteks ve yan nefler üzerindeki galeriler ise Konstantinopolis kiliselerinin Kilikia ve Isauria'ya yaptığ 1 mimari etki olarak kabul edilmektedir (Hellenkemper, 1994, 225; Aydın, 2003a, 419).

Kilikia kiliseleri arasında, Hierapolis Kastabala kiliselerinin de içinde bulunduğu bir grup, bölgedeki diğerlerinden farklı ancak kendi içlerinde benzer özellikler taşır. Gertrude Bell bu grupta yer alan Kadirli Alacami ile Hierapolis Kastabala kiliseleri arasındaki mimari benzerlikleri kayıt altına alan ilk araştırmacıdır (Bell, 1906, 10). Bu benzerliklerden yola çıkılarak yapılan çalışmalar sonucunda Kilikia Ovası'nın kuzeydoğusunda ve Torosların eteklerinde yer alan yirmi kadar kilisenin, Dağlık Kilikia, Kapadokya ve Suriye kiliselerinden farklı mimari özellikler gösterdiği saptanmıştır (Bayliss, 1997, 58).

Büyük oranda devşirme malzeme içeren bezemeli düzgün kesme yontma taşla inşa edilmiş bu yapılarda apsis çokgen formdadır ve kemerli üç geniş açıklıkla bölümlenir. Yaygın görülen köşe odaları tek tip özellik göstermezler. Narteks yaygın değildir. Narteksli örneklerde bu kısım ya yapının orijinal tarihinden daha geç inşa edilmiştir veya batı duvarına sonradan eklemlenmiştir. Mekanların dışarı açılımlarında batı duvarında tekli veya üçlü açıklık, naos duvarlarında geniş kemerli açıklıklar benzeri düzenlemeler görülür. Avlu

18 Feld, Kuzey Kilise'nin büyük payelerinin yan neflerin ve orta nefin tonoz örtü sistemine işaret edebileceğini söyler (Feld 1986, 78). Ancak biz yapının boyutlarını ve bölgede benzerleri için önerilen örtü sistemini göz önünde bulundurarak örtü sisteminin ahşap, dolayısıyla bazilikanın Helenistik Bazilika olduğunu düşünmekteyiz.

19 Kubbeli veya tonozlu bazilikalarda bile bu kısımlarda pişmiş toprak örtü sistemi korunmaktaydı (Hill 1996, 14).

20 Karakabaklı Bazilika 15 x 35 m., Alahan Batı Kilisesi 16 x 36.5 m., Çatıören Bazilika 14.8 x 34.4 m. (Varinlioğlu 2013, 208-209, dipnot 27). 
genelde mevcut değildir. Suriye etkili bezemeler yaygındır ancak düzensiz ve ham üslup özellikleri gösterirler. Bu grupta yer alan yapılar Kilikia Ovası'nda Kilikia Secunda'nın başkenti Anazarbos, Hierapolis Kastabala, Kadirli Flavias ve Karlık olmak üzere dört bölgede yoğunlaşır. Ovanın kuzeyinde Akdam, Akkilise, Akören I ve II, Ferhatlı, Göreken Yayla, Karacauşağı, Kastalan ve Mazılık bölgelerinde de benzer özellikler taşıyan oldukça fazla kilise vardır (Bayliss, 1997, 58).

Kiliselerde devşirme malzeme kullanımı Hıristiyanlığa geçiş sürecinde bölgedeki benzerlerinde de görülen bir uygulamadır. Mimari anlamda ikinci kullanım, zaman içinde değişen sosyo-ekonomik koşullar nedeniyle yapıların veya yapı elemanlarının, gerekli mimari uyarlamalarla, yeni işlevler yüklenmesi olarak tanımlanabilir (Niewöhner, 2018, 243264). İkinci kullanım, yapı elemanlarının bir başka yapıda malzeme olarak kullanılmasından (spolia), yapının tamamının başka bir işlev yüklenmesine kadar geniş bir uygulama alanına sahiptir. MS 320 yılından başlayarak imparatorluk kanunlarıyla, yapıların ve mimari malzemenin ikinci kullanımlarına bir düzen getirilmeye çalışılmıştır. Üçüncü yüzyıl içinde bozulan ekonomi ve Hıristiyanlaşmaya başlayan bir imparatorluğun ideolojisi, anıtların ikinci kullanımının iki ana nedeni olarak ortaya çıkmaktadır. Dönem koşulları göz önüne alındığında ikinci kullanım surun arkasına çekilmek zorunda kalındığı için alanı giderek daralan kentlere yeni yapılar için yer sağlaması, yapı ustalarının sayıca yetersizliği nedeniyle nitelikli işgücüne çok fazla gereksinmeksizin yeni inşa faaliyetlerinin gerçekleştirilmesinde kolaylık sağlaması, işlevini yitirmiş anıtların bir biçimde korunmaya devam edilmesi gibi bir dizi olanak sağlamıştır. Yapıların ve/veya malzemelerin ikinci kullanımlarının, dönemin mimari aktivitesinin sürdürülmesine katkısının yanı sıra dönemin değişen estetik anlayışı ile etkileşim içinde, Geç Antik ve Bizans dönemleri mimarilerinde de belirleyici rolü olmuştur. Mimari elemanların devşirilmesi bina ölçeğinde mimariyi etkilerken, yapıların ikinci kullanımı da kent profili ölçeğinde etkili olmuştur (Ceylan, 2003, 73-74).

Bölgedeki kiliselerin boyutları ve sayısı demografik yapıya dair net bir bilgi vermemektedir. Ancak bu verilerden bölgenin ve hayırseverlerin refah seviyesine dair sonuçlar çıkartılabilir. Anadolu'nun güneyinde üçüncü yüzyılın ikinci yarısında görülen ekonomik gerilemenin ardından, beşinci ve altıncı yüzyıllarda bölgede tarıma dayalı ticaretin artması ile birlikte ciddi anlamda bir zenginleşme yaşanmıştır. Bu durum kiliseler ve benzerleri için dönemin kamusal alandaki doğrudan yansımalarıdır (Hellenkemper, 1994).

Post-Yapısalcı Eleştiri, dinsel praksisler bütününde Hıristiyanlığın iki temel refleks üzerinden bir iktidar modeli kuruyor olması üzerinde durmuştur. Bunlardan ilki Foucault'nun “Pastoral İktidar” şeklinde adlandırdı̆̆ 1 örüntü dizgesi (Foucault, 2016a, 209, 221-227; 2016b, 211, 214-215, 264-265), diğeri ise Bourdieu'nün “Geçiş Törenleri” şeklinde adlandırdı̆̆ 1 “Simgesel İktidar” modelidir (Bourdieu, 2016, 205-213, 284-290). 
Foucault, “dispositif” olarak adlandırdığı stratejik iktidar şemasını, özellikle de yerelde, Hıristiyan toplumsal ilişkiler ağını modelleyerek inşa etmiştir. Bu türden bir iktidar kati dinsel kökenli bir sistemdir (Pavlus'un inşa anlayışında olduğu üzere -bizce bu inşanın erken evreleri Platon, geç evreleri Augustinus tarafından tasarlanmıştır). Sistem paradigmik yapıyı vaatler üzerinden kurar (öte dünya - cennet). Bu vaadin karşılığında yerine getirilmesi gereken yaşam pratiği vardır (düzenli yapıyı öğrenme, uyum sağlama, kabul edilme, sürdürme, aktarma aşamaları). Yaşamın denetim altına alınması gerekmektedir (Urhan, 2013, 15-25, 120-121; Akay, 2016, 11). Bu yaşam pratikleri hem grup hem de birey üzerinde uygulanır ki Pastoral İktidar şeklinde adlandırılır. Buradaki Hıristiyanlığın temel varoluşu (iktidar refleksleri) itiraf edimi üzerinden güvence altına alınmış olmaktadır (Foucault, 2016a, 209; Foucault, 2017, 19; Akay, 2016, 26-27). Kişinin itirafı, sisteme sağladığı uyumun en kuvvetli işaretidir (bilinçdışındaki antropomorfik gösterge - kişinin kendi iradesiyle "sürünün" üyesi olma, kabul edimi). Bilgi, iktidar aygitı üretmektedir (Akay, 2016b, 116-117). Foucault'nun söz konusu praksisleri doğu (Piro, 2008, 36-41) geleneklerinde kutsallık atfedilmiş uzamlar ve batı geleneğindeki kilise (Hirst, 1993, 53-56) kütlesi içinde gerçekleşmiştir. Çünkü mimari kurumsal yapılar birer bakış kurarlar, bu sayede görülebilir olurlar (Akay, 2016, 13). Foucault'ya göre iktidarın iki somut unsuru vardır. "Görülebilir Olan" ve "Söylenebilir Olan" (Urhan, 2013, 15-25, 111, 115, 184, 120-121; Akay, 2016b, 112; Deleuze, 2019, 61-80). Hıristiyanlık ikisi için de elit birer üretim gerçekleştirmiştir; Anıtsal Kiliseler ve Yeni Ahit.

Bourdieu ise bu sürekliliğin (iktidar) Geçiş Törenleri adını verdiği üretimsel ve aktarımsal edimler dizisi ile sağlandığını öne sürmektedir; "Alıcıya grubun gerçek bir üyesi olarak kendi varlığına, meşruiyetine dair güven vermek ama aynı zamanda gruba da hem takdis olmuş ve takdis edebilen grup olarak varoluşunun hem de ürettiği, yeniden ürettiğ $i$ ve alıcının almayı kabul ederek var ettiği toplumsal kurguların gerçekliğinin güvencesini verir" (Bourdieu, 2016, 205-213, 284-290). Bu geri dönülemez farklar inşa eden Geçiş Törenleri ortak görme ve ayırma ilkeleri oluşturarak, Bourdieu'nün deyişiyle örgütsel bir yapı ve pratikleri düzenleyici merci olarak, kalıcı eğilimler oluşturmaya yönelik sürekli bir eylemdir. İnsanlar kuralları kendi arzuları gibi hissederler (Akay, 2016b, 135). Bu süreklilik onda "Mutlak İktidar"1 oluşturur. Mutlak İktidar, öngörülemez olma ve başkalarını mutlak bir belirsizliğe mahkûm etme iktidarı olarak "bekleten" bir iktidar modelidir (post-psikolojik çile aşaması). Foucault'nun ortaya koyduğu üzere paradigmik yapının günah çıkarma ve bağışlanma üzerinden sürdürülmesi (güvence altına alınması), Bourdieu'de sonu belirsiz bir süre olan ancak nihai süreçte olumlanmış bir cennet düşüncesine kavuşma umudunu her an güçlendiren bir sürece dönüşür. Antik Kastabala kentinde yaşanmış süreç budur ve MS 5-6. yüzyıllarda yapılmış ikiz Kuzey ve Güney Kilise yapıları bu yaşanmışlığın işaretleridir. 
Teşekkür: Kastabala Kazı Başkanı Sayın Prof. Dr. Turgut H. Zeyrek’e, vermiş olduğu izin, makalenin her aşamasında yapmış olduğu yardımlar ve göstermiş olduğu nezaket için teşekkürlerimizi sunmayı bir borç biliriz. Yapının örtü sistemi ile ilgili görüşleri ve kaynak önerileri için Sayın Prof. Dr. M. Sacit Pekak’a teşekkür ederiz. Büyük bir cömertlikle paylaştığı değerli fikirleri ve kaynak önerileri/yardımı için Sayın Prof. Dr. Mustafa Hamdi Sayar'a ne kadar teşekkür etsek azdır.

Hakem Değerlendirmesi: Dış bağımsız.

Çıkar Çatışması: Yazarlar çıkar çatışması bildirmemiştir.

Finansal Destek: Yazarlar bu çalışma için finansal destek almadığını beyan etmiştir.

Peer-review: Externally peer-reviewed.

Conflict of Interest: The authors have no conflict of interest to declare.

Grant Support: The authors declared that this study has received no financial support.

\section{Kaynakça/References}

Akay, A. (2016a). Michel Foucault'da İktidar ve Direnme Odakları. Ankara: Doğu-Batı Yayınları.

Akay, A. (2016b). Tekil Düşünce. Modern Fransız Toplumbilim Düşüncesi. Ankara: Doğu-Batı Yayınları.

Akurgal, E. (1987). Griechische und römische Kunst in der Türkei. Münih.

Andrade, N. (2011). Local authority and civic Hellenism: Tarcondimotus, Hierapolis-Castabala and the cult of Perasia. Anatolian Studies, 61, 123-132.

Aydın, A. (2003a). Die christliche architektur in Kilikien und Isaurien am beispiel der kirche von Demirciören. Belleten, 67, 415-419.

Aydın, A. (2003b). Mersin-Silifke, Seyranlık Köyü Geç Antik-Bizans Dönemi Mimarisi, 21. Araştırma Sonuçları Toplantısı, 1. Cilt, Ankara, 217-229.

Bayliss, R. (2001). Provincial Cilicia and the Archaeology of Temple Conversion. (Doktora Tezi). University of Newcastle upon Tyne Department of Archaeology.

Bayliss, R. (1997). The Alacami in Kadirli: Transformations of a Sacred Monument. Anatolian Studies, 47, 57-87.

Bell, G.L. (1906). Notes On A Journey Through Cilicia And Lycaonia, Revue Archéologique. Quatrième Série, T. 7, (Janvier-Juin), 1-29.

Bent, T. (1890). A Journey in Cilicia Tracheia. Journal of Hellenic Studies, 12, 206-224.

Ceylan, B. (2003). Temple-Church in Olba and The Reuse of Antique Monuments in Late Antiquity. Olba VIII, 73-82.

Ceylan, B. (2001). Geç Antik Dönem Batı Anadolu Bazilikaları, Olba IV, 189-203.

Davis, E.J. (1879). Life in Asiatic Turkey. A Journey of Travel in Cilicia Pedias and Trachaea. Londra: Isauria and parts of Lycaonia, 128-134.

Deleuze, G. (2019). Foucault. (B. Yalım ve E. Koyuncu, Çev.). İstanbul: Norgunk Yayıncılık.

Dupont-Sommer, A. \& Robert, L. (1964). La déesse de Hierapolis Castabala (Cilicie). Paris.

Duygu, Z. (2017). Hiristiyanlık ve Imparatorluk: Geç Antikçağ’da Kilise-Devlet İlişkileri ve Kristoloji Paradigmalart. İstanbul: Divan Kitap.

Duygu, Z. (2018). İsa, Pavlus ve İnciller: Hıristiyanlık Neden ve Nasıl Ortaya Çıktı?, İstanbul: Düşün Yayıncilik.

Dvornik, F. (1990). Konsiller Tarihi, İznik'ten II. Vatikan'a. (M. Aydın, Çev.). Ankara. 
Elton, H. (2013). Late Roman Churches in the Upper Göksu Valley, Isauria, Rough Cilicia: New Historical and Archaeological Approaches. Michael C. Hoff \& Rhys F. Townsend (Eds.), Oxford, Oxbow Books,.

Elton, H. \& Equini-Schneider, E. \& Wannagat, D. (2007). Temple to Church: The transformation of religious sites from paganism to Christianity in Cilicia. Tapınaktan Kiliseye: Kilikya'da Putperestlikten Hıristiyanlığa Geçişte Dini Yerleşmelerin Dönüşümü. (B. Taşpınar, Çev.). İstanbul: Ege Yayınları.

Feld, O. (1965). Beobachtungen an spätantiken und frühchristlichen Bauten in Kilikien: Bericht über eine Reise. Römische Quartalschrift, 60, 131-143.

Feld, O. (1986). Die beiden Kirchen in Hierapolis-Kastabala. Feld \& Peschlow. (Eds.). Studien zur spätantiken und byzantinischen Kunst, Friedrich Wilhelm Deichmann gewidmet. Monographien des RömischesGermanisches Zentralmuseums 10.1, Bonn. 77-86.

French, D. (2016). Roman Roads and Milestones of Asia Minor: The Pilgrim's Road. Ankara: British Institute of Archaeology.

Foucault, M. (2016a). Entelektüelin Siyasi İşlevi. I. Ergüden ve T. Birkan. (Eds.). İstanbul: Ayrıntı.

Foucault, M. (2016b). Özne ve İktidar. I. Ergüden ve O. Akınhay (Eds.). İstanbul: Ayrıntı.

Foucault, M (2017). Hermenötiğin Kökeni. Kendilik Hakkında - Dartmouth Konferansları. (Ş. Solmaz. Çev.). İstanbul: Ayrıntı.

Gough, M. (1955). Early Churches in Cilicia, Byzantinoslavica, 16, 201-11.

Gough, M. (1961). The Early Christians, Thames and Hudson, Londra.

Gough, M. (1972). The Emperor Zeno and Some Cilician Churches. Anatolian Studies, 22, 199-212.

Heberdey, R. \& Wilhelm, H. (1896). Reisen in Kilikien ausgeführt, 1891 und 1892 im Auftrage der kaiserlichen Akademie der Wissenchaften, Philosophisch-Historische Klasse, 44, Viyana.

Hellenkemper, H. \& Hild, F. (1986). Neue Forschungen in Kilikien, Verlag der Österreichischen Akademie der Wissenchaften, Veröffentlichungen der Kommission für die Tabula Imperii Byzantini, Band 4.Viyana.

Hellenkemper, H. (1986). Die Kirchenstiftung des Kaisers Zenon im Wahlfahrtsheiligtum der Heiligen Thecla bei Seleukeia. Wallraf Richartz Jahrbuch, 47, 63-90.

Hellenkemper, H. (1994). "Early Church Architecture, Southern Asia Minor. (der. K. Painter), Londra: Churches Built in Ancient Times, 213-238.

Hengel, M. \& Schwemer, A.M. (1997). Paul Between Damascus and Antioch: The Unknown Years. (J. Bowden, Çev.) Louisville, Westminster John Knox.

Hill, S. (1996). The Early Byzantine Churches of Cilicia and Isauria. Variorum, Hampshire.

Hild, F. \& Hellenkemper, H. (1984). Kommagene-Kilikien-Isaurien. Reallexikon zur Byzantinischen Kunst, 4, 182-356.

Hild, F. \& Hellenkemper, H. (1990). Kilikien und Isaurien, Tabula Imperii Byzantini. 5/1, Österreichische Akademie der Wissenschaften, Philosophisch-Historische Klasse Denkschriften, 138, 293-294, Viyana.

Hirst, P. (1993). Foucault and Architecture. AA Files, Architectural Association School of Architecture, 26, 52-60.

Honigmann, E. (1939). La Liste Originale Des Pères De Nicée: A propos de 1'Évêché de «Sodoma » en Arabie. Byzantion, Vol. 14, No. 1, s. 17-76.

Kaçar, T. (2003). Cilician Bishops and Fourth-Century Church Politics, Olba VIII, 109-128.

Kaplan, D. (2009). Roma Imparatorluk Çăğ’nda Kilikia: Kent Kurulumları, Bayındırlık Hareketleri ve Imparatorluk Kültü. Mersin Sempozyumu 19-22.11.2008, Mersin, 90-96. 
Kortanoğlu, R.E. (2018a). Varlık ve Tapınak, Eski Yunan Tapınağının Kavramsal İnşası Üzerine Arkitektonik Bir Deneme. Ankara: Bilgin Kültür Sanat.

Kortanoğlu, R.E. (2018b). Political-Economy Discourses in Metaphorique Construction of Greek Temple, 19th International Congress of Classical Archaeology Cologne/Bonn (Germany), 22-26.05.2018, Archaeology and Economy in the Ancient World. Abstracts, 397-398.

Kortanoğlu, R.E. (2019). Logocentric Structures, Platon and Dual Worshipping Phenomenon, 12-13.12.2019 VI. Yıldız Teknik Üniversitesi Sosyal Bilimler Kongresi. Tam Metin Bildiri Kitabı. İstanbul: Yıldız Teknik Üniversitesi, 281-290.

Krinzinger, F. \& Reiter, W. (1993). Archaeologische Forschungen in Hierapolis Kastabala, 269-287.

Kurt, M. (2010). Roma Egemenliğinde Kilikya ve Roma İç Savaşlarının Bölgedeki Yansımaları. Tarih Araştırmaları Dergisi, XXV/2, 483-501.Mathews, T.F. (1977). The Early Churches of Constantinople, Architecture and Liturgy. Pennsylvania State University Press.

Niewöhner, P. (2018). Doğu ve Batı'da Çeşitlilik (Varietas), Devşirme Malzeme (Spolia) ve Antik Çă̆'ın Sonu, Devşirme Malzemenin (Spolia) Yeniden Doğuşu. Antik Çă̆'dan Osmanlı'ya Anadolu'da Objelerin, Materyallerin ve Mekanların Sonraki Yaşamları. S. Yalman, I. Jevtiç (Eds.), 243-264, İstanbul: Koç Üniversitesi.

Norberg-Schulz, C. (1979 ve 1991). Genius Loci, Towards a Phenomenology of Architecture. New York: Rizzoli.

Okan, C. (2019). Mitoslar ve Tasvirler Işı̆̆̆ında Antik Ege Coğrafyasında Dişi Tanrısal Figürler: Kök, Karışım ve Değiş̧im. (Yüksek Lisans Tezi). Anadolu Üniversitesi, Sosyal Bilimler Enstitüsü, Eskişehir.

Öğüş, E. (2019). Kutsal Alanların Geç Antik Dönem'deki İkincil Yaşamları: Kiliseye Dönüşüm ve Ad Sanctos Gömüler. MSGSÜ Sosyal Bilimler Dergisi, 2019/3, 19, 85-98.

Özyıldırım, M. ve Yeğin, Y. (2019). İmparator Zeno Dönemi’nde Cilicia ve Isauria'da Kilise İnşa Faaliyetleri. MSGSÜ Sosyal Bilimler Dergisi, 2019/3, 264-279.

Piro, J.M. (2008). Foucault and the Architecture of Surveillance: Creating Regimes of Power in Schools, Shrines and Society. Educational Studies, 44, 30-46.

Pohl, D. \& Sayar, M.H. (2004). Perasia in Hierapolis-Kastabala, Asia Minor Studien 53, Bonn, 107-118.

Quien, M.L. (1958). Oriens christianus: in quatuor patriarchatus digestus: quo exhibentur ecclesiae, patriarchae caeterique praesules totius orientis. (1740 nüshasının tıpkıbasımı), Akademische Druck-U. Verlagsanstalt.

Sayar, M.H. (1999a). Kilikya'da Tanrılar ve Kültler, Olba, II.1, 131-154.

Sayar, M.H. (1999b). Antik Kilikya’da Şehirleşme. Ankara: XII. Türk Tarih Kongresi, 193-216.

Sayar, M.H. (2000). Çukurova'nın Kutsal Kenti Kastabala. Arkeoloji ve Sanat, 99, 7-14.

Sayar, M.H. (2001). Tarkondimotos, seine Dynastie, seine Politik und sein Reich. Varia Anatolica XIII, 373-380.

Sayar, M.H. (2016). The Temple of Uzunoğlan Hill in Smooth Cilicia, Colloquia Antiqua 17, 101-116.

Sayar, M.H. (2019a). Römische StraBen und Meilensteine im Ebenen Kilikien, Roman Roads New Perspectives. A. Kolb (Ed.), 147-165, Berlin.

Sayar, M.H. (2019b). Roma Eyaleti Olarak Kilikia (Provincia Cilicia), Hellenistik ve Roma Dönemlerinde Anadolu. Krallar, Imparatorlar, Kent Devletleri. O. Tekin (Ed.), (s. 334-355) İstanbul: Yap1 Kredi Yayınlar1. 
Sayar, M.H. (2020a). Spätantike Siedlungen im Ebenen Kilikien. Mitteilungen zur spätantiken Archäologie und Kunstgeschichte 7, 2020, 54-59.

Sayar, M.H. (2020b). Local Donors and Euergetism in the Cities of Cilicia Pedias Between the First Century BC and Second Century AD, Philanthropy in Anatolia Through The Ages. O. Tekin, C.H. Roosevelt, E. Akyürek, (Eds.). (s. 73-82). İstanbul: Koç Üniversitesi.

Spawforth, T. (2006). The Complete Greek Temples, Thames and Hudson. Londra.

Swartz, D. (2018). Kültür ve İktidar, Pierre Bourdieu’nün Sosyolojisi. (E. Gen, Çev.). İstanbul: İletişim.

Tobin, J. (2001). The Tarcondimotid Dynasty in Smooth Cilicia. Varia Anatolica XIII, 381-387.

Türkmen, M. (2007). Pamphylia ve Kilikia'da Severuslar Dönemi Mimari Bezemesi. (Doktora Tezi). İstanbul Üniversitesi, Sosyal Bilimler Enstitüsü, İstanbul.

Urhan, V. (2013). Michel Foucault ve Düşünce Sistemleri Tarihi, Arkeoloji, Soykütüğü, Etik. İstanbul: Say Yayınları.

Ünal, A. (2006). Hitit İmparatorluğu'nun Yıkılışından Bizans Dönemi’nin Sonuna Kadar Adana ve Çukurova Tarihi. ÇÜ Sosyal Bilimler Enstitüsü Dergisi, 15/3, 67-102.

Varinlioğlu, G. (2013). Rural Habitat in the Hinterland of Seleucia ad Calycadnum during Late Antiquity, Rough Cilicia: New Historical and Archaeological Approachess. Michael C. Hoff, Rhys F. Townsend. (Eds.), Oxbow Books, Oxford.

Wilson, M. (2003a). Cilicia, the First Christian Churches in Anatolia. Tyndale Bulletin, 54.1., 15-30.

Wilson, M. (2003b). Was Paul A Cilician, A Native of Tarsus? A Historical Reassessment. Olba VIII, 93-107.

Yalduz, A. (2003). Konsillerin Hıristiyanlık Tarihindeki Yeri ve İznik Konsili. Uludağ Üniversitesi İlahiyat Fakültesi Dergisi, 12/2, 257-296.

Zeyrek, T.H. (2011). Kastabala Antik Kenti Kazıları 2009. (s. 96-116). Ankara: 32. Kazı Sonuçları Toplantısı, 2. Cilt

Zeyrek, A.N. (2018). Hierapolis-Kastabala. İstanbul: Ege Yayınları. 


\section{Figürler}

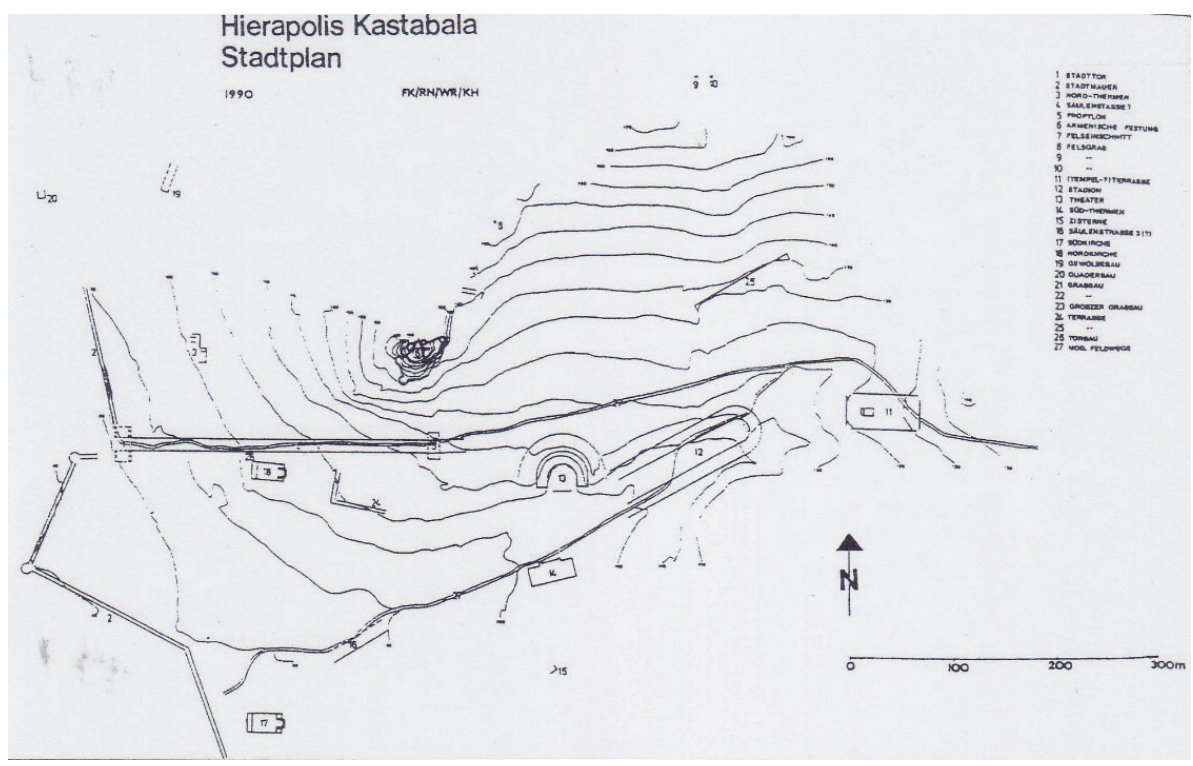

Figür 1. Kastabala Planı (Krinzinger ve Reiter 1993).

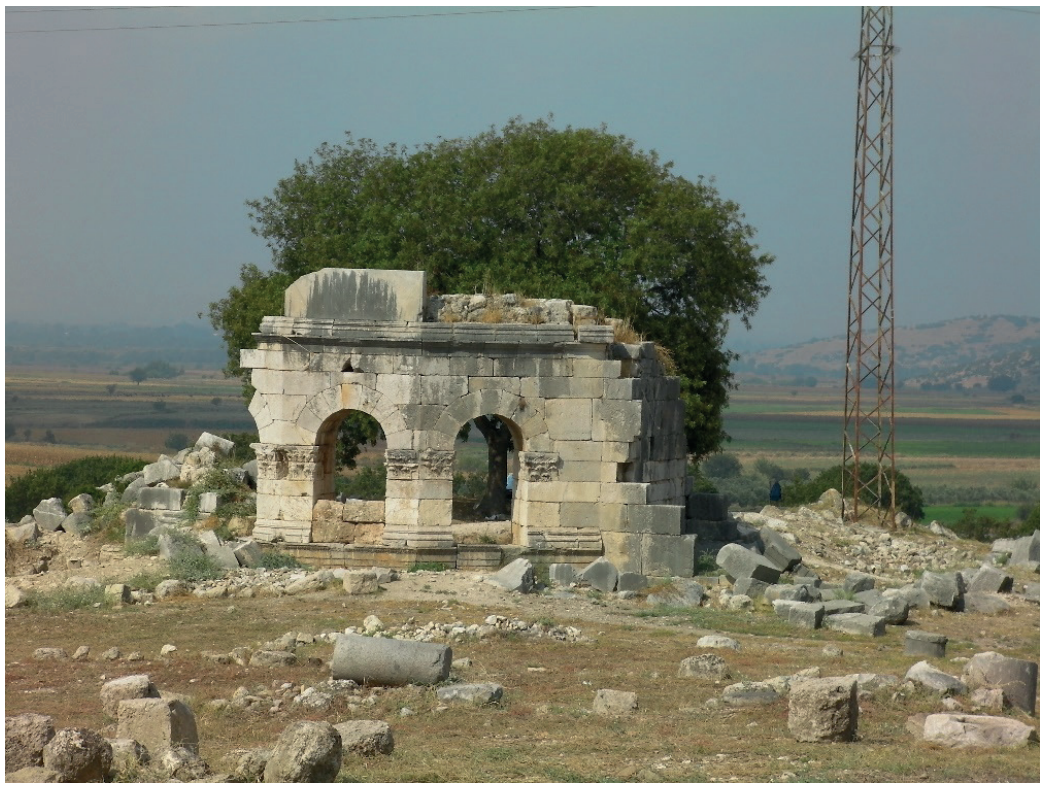

Figür 2. Kastabala. Kuzey Kilise. Apsis. Façade. (R. Eser Kortanoğlu arşivi). 


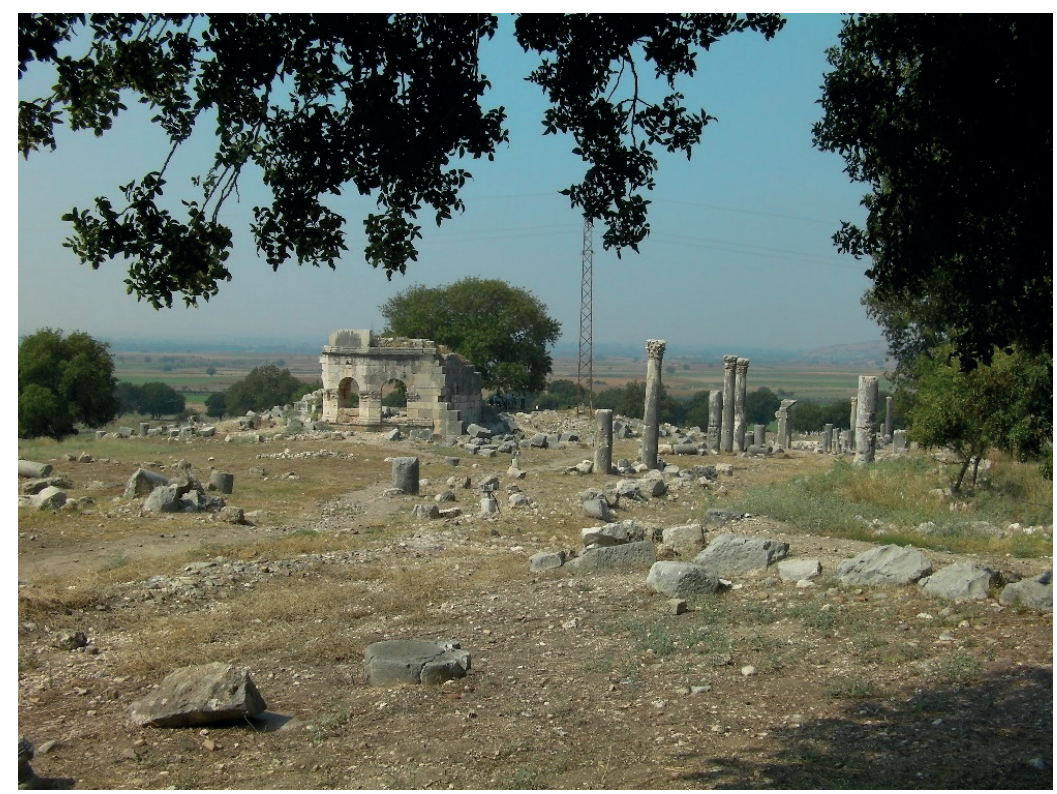

Figür 3. Kastabala. Kuzey Kilise ve sütunlu cadde. (R. Eser Kortanoğlu arşivi).

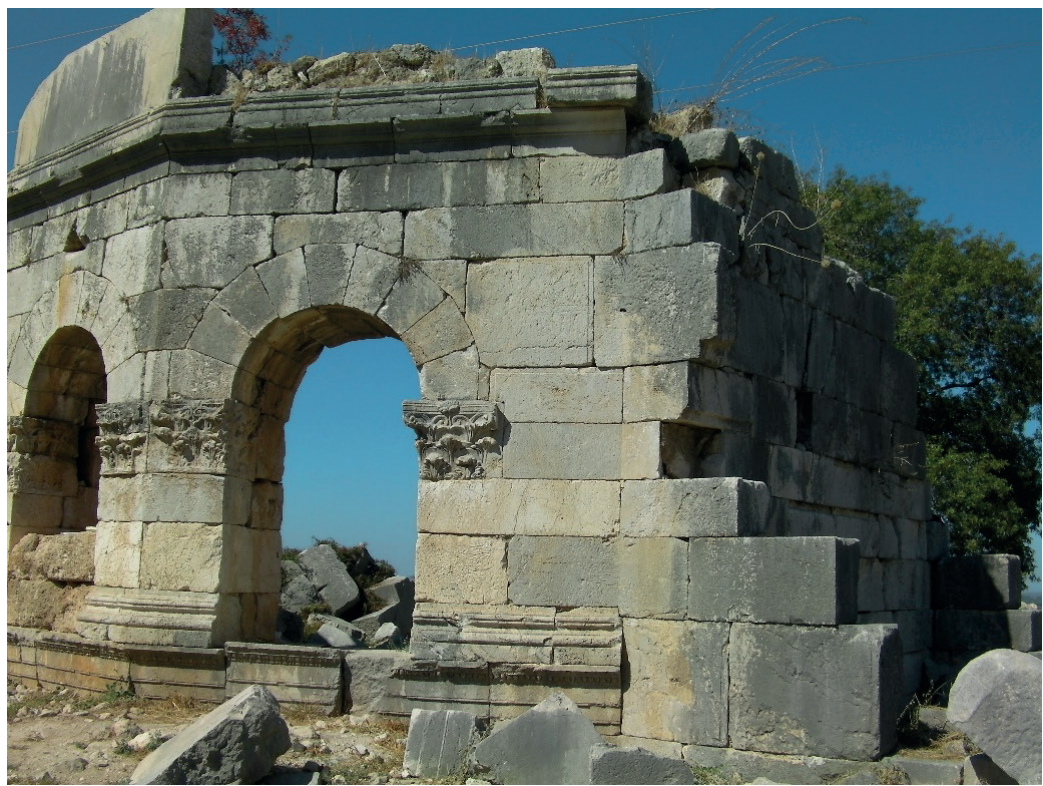

Figür 4. Kastabala. Kuzey Kilise. Façade. Detay. (R. Eser Kortanoğlu arşivi). 


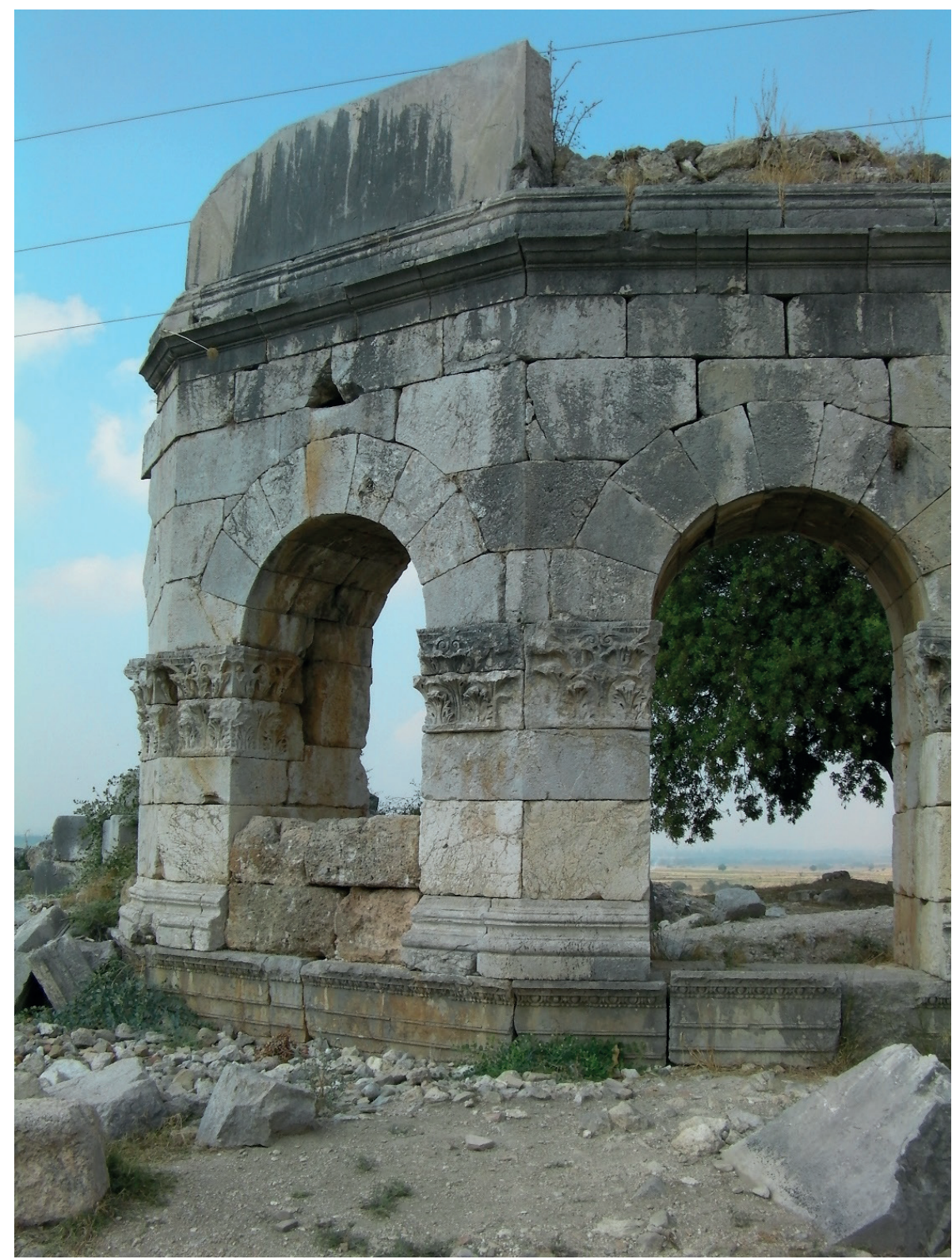

Figür 5. Kastabala. Apsis. Façade. Detay. (R. Eser Kortanoğlu arşivi). 


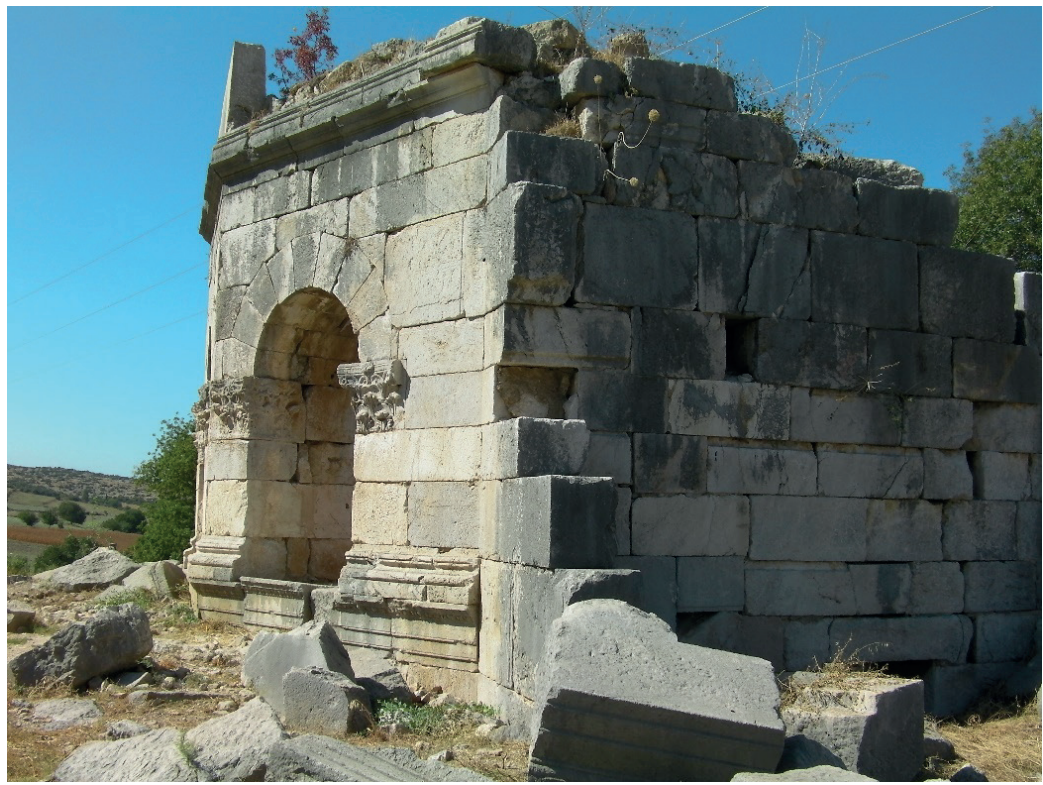

Figür 6. Kastabala. Apsis ve Kuzey uzun kenar. (R. Eser Kortanoğlu arşivi).

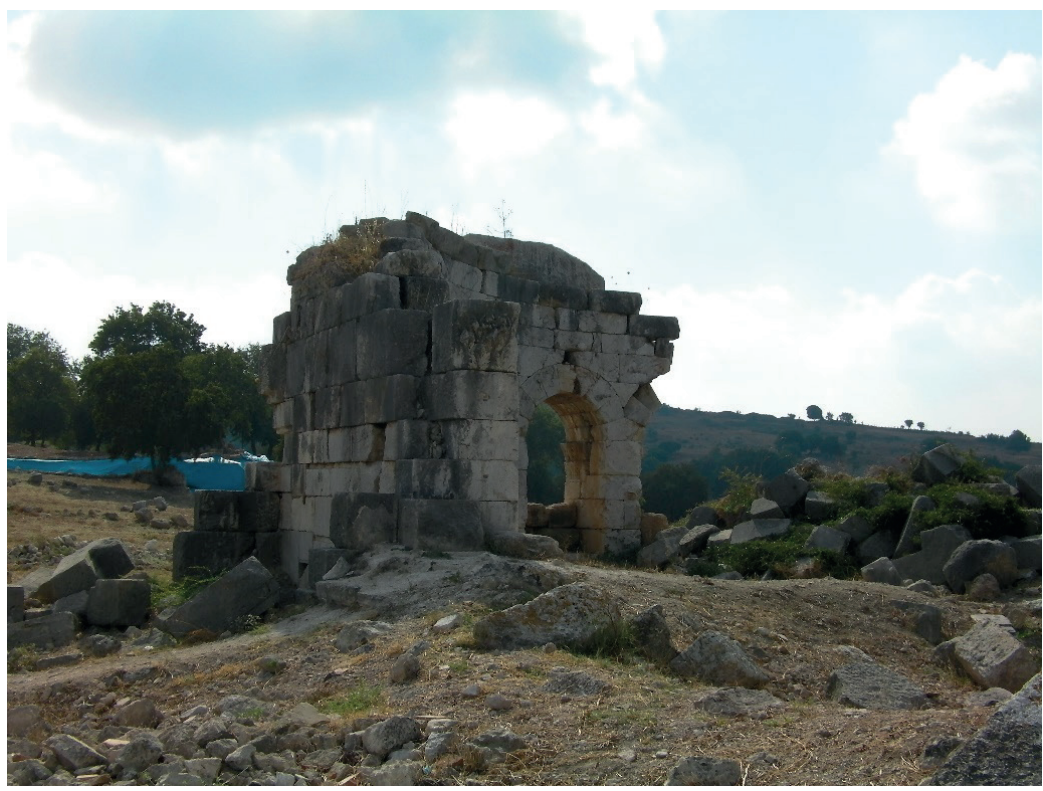

Figür 7. Kastabala. Kuzey ve Batı cepheler. (R. Eser Kortanoğlu arşivi). 


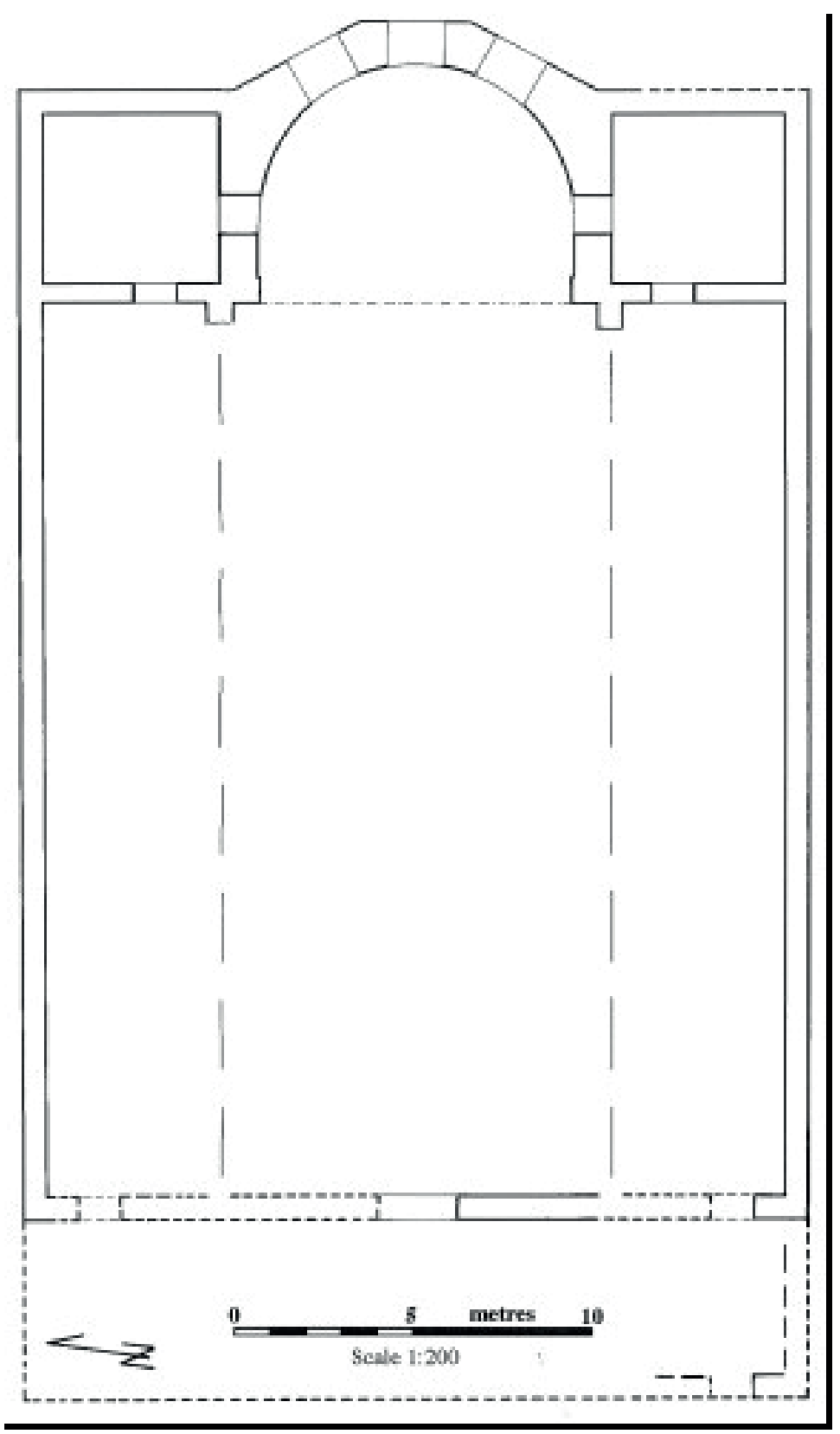

Figür 8. Kastabala. Kuzey Kilise. Plan (Hellenkemper 1994, 233, fig. 23). 


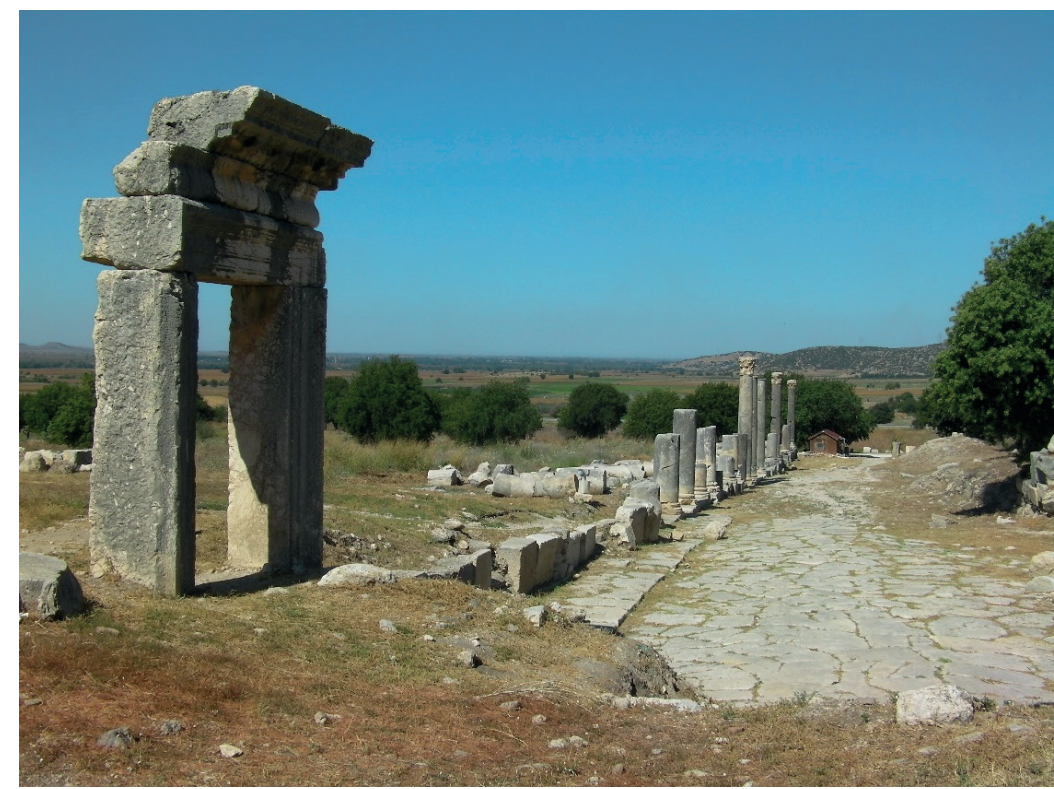

Figür 9. Kastabala. Sütunlu cadde ve kilisenin anıtsal kapısı. (R. Eser Kortanoğlu arşivi).

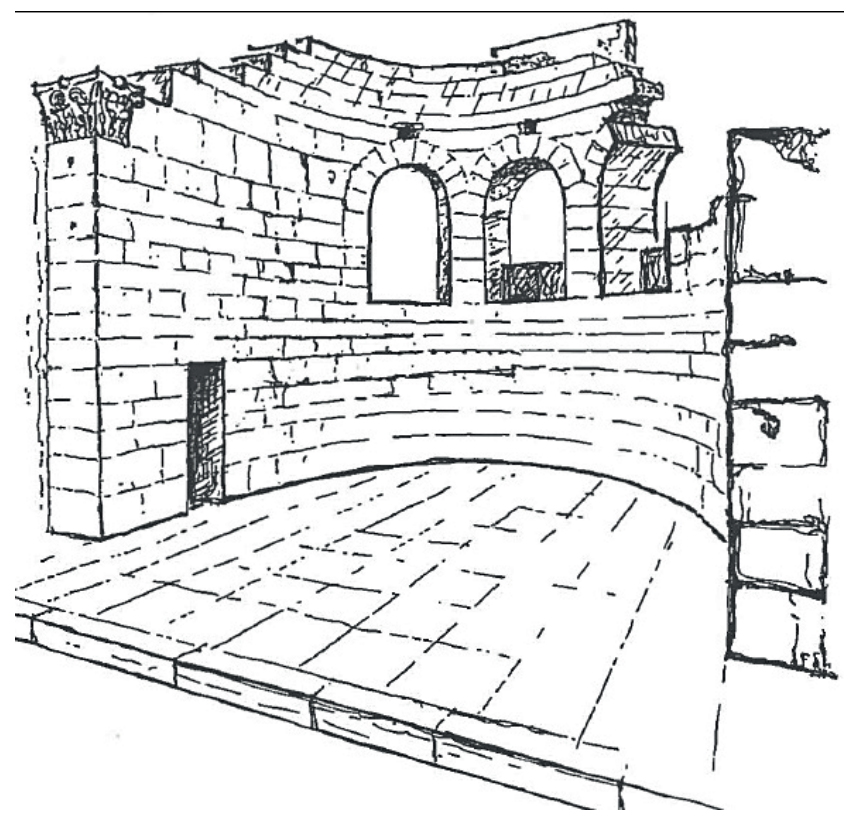

Figür 10. Kastabala. Kuzey Kilise restitüsyon (Feld 1986, 81, fig. 3). 